Micro-Determinants of Informal Employment in The Middle East and North Africa Region

Diego F. Angel-Urdinola Kimie Tanabe

January 2012

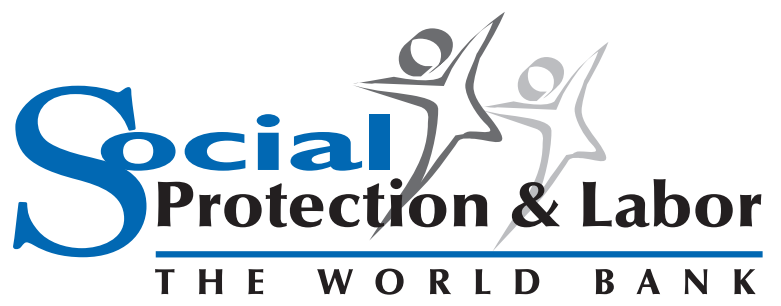




\title{
Micro-Determinants of Informal Employment in The Middle East and North Africa Region
}

\author{
Diego F. Angel-Urdinola and Kimie Tanabe
}

January $2012^{1}$

\begin{abstract}
This note assesses the main micro-determinants of informal employment in the Middle East and North Africa (MENA) region from a human development stand point. It's main purpose is to quantify the patterns of labor informality (defined as the share of all employment with no access to social security) according to age, gender, education level, employment sector, profession, marital status, employment status, and geographic area in a selected group of countries in the region. Results indicate that the size of the public sector and the size of the agriculture sector are perhaps the main correlates of informality in the region. Countries where agricultural employment still constitutes a large share of overall employment (such as Morocco and Yemen) are associated with higher levels of overall informality. On the contrary, countries with larger public sectors and more urbanized such as Egypt, Syria, and Lebanon, display lower levels of overall informality. The existence of a large public sector, still associated with generous benefits and better employment quality, creates an important segmentation between public and private employment in many MENA countries. Informality rates are very high among youth between ages fifteen and twenty-four. After age twenty-four, informality decreases rapidly until individuals reach prime working age (forty to forty-five years). This rapid decrease in informality rates goes hand in hand with a rapid increase in public sector employment, suggesting that informal workers enter into public sector jobs as they move from youth into adulthood. Results also indicate that the average worker in the informal sector is disadvantaged versus the average worker in the formal sector, as they are uncovered against social risks and are generally employed in low-productivity/low pay jobs.
\end{abstract}

JEL Classification: J22, J24, J48, J64, L31, 017

Keywords: informality, informal sector, informal employment, labor markets, Middle East and North Africa, returns to education

Authors: Diego F. Angel-Urdinola (dangelurdinola@worldbank.org)

Kimie Tanabe (ktanabe@worldbank.org)

\footnotetext{
${ }^{1}$ This note was prepared as a Background paper for the regional study "Striving for Better Jobs: The Challenge of Informality in the Middle East and North Africa Region". The authors thank Roberta Gatti for her support, guidance, and helpful insights during the preparation of the work; and Caroline Freund, Mohamad Allouche, Anne Hilger, Norman Loayza, William Maloney, Jaime Saenz, Joana Silva, and May Wazzan and for their useful comments and inputs.
} 


\section{Introduction}

1. This note aims to understand the main micro-determinants of informal employment in the Middle East and North Africa (MENA) region from a human development stand point. The main purpose of this note is to quantify the patterns of labor informality according to age, gender, education level, employment sector, profession, marital status, employment status, and strata in a selected group of MENA countries. The study looks at informality through the human development angle and focuses specifically on informal employment. In line with this approach, the working definition adopted by the report for informality is "lack of social security coverage" (usually understood as a pension, or if a pension system does not exist, as health insurance), which captures well the vulnerability aspect associated with informal employment.

2. Some countries in the MENA region are among the most informal economies in the world. Informality is a matter of concern among policymakers and the business community throughout the world. Impacts on productivity and growth, losses in fiscal revenues, and equity issues related to the existence of unprotected workers lacking health insurance and pension protection are important concerns associated with a significant share of the labor force operating informally. A recent review of informal labor markets in the MENA region (see Loayza and Wada, 2010) reveals that some countries in the region are among the most informal economies in the world. The typical country in MENA produces about 27 percent of its GDP and employs 67 percent of its labor force informally (using the Schneider Index and the share of the labor force with pension coverage, respectively) (Figure 1). These are remarkable statistics, especially from a human development perspective. These stylized facts indicate that more than two thirds of all the workers in the region may not have access to health insurance and/or are not contributing to a pension system that would provide income security after retirement age. At the same time, from a fiscal perspective, these results indicate that about one third of total economic output in the region remains undeclared and therefore not registered for tax purposes. In this context, it is important to study and understand what the main characteristics of informal employment in MENA are and how these characteristics vary across countries in the region.

Figure 1: Informality in MENA vs. Other Regions.
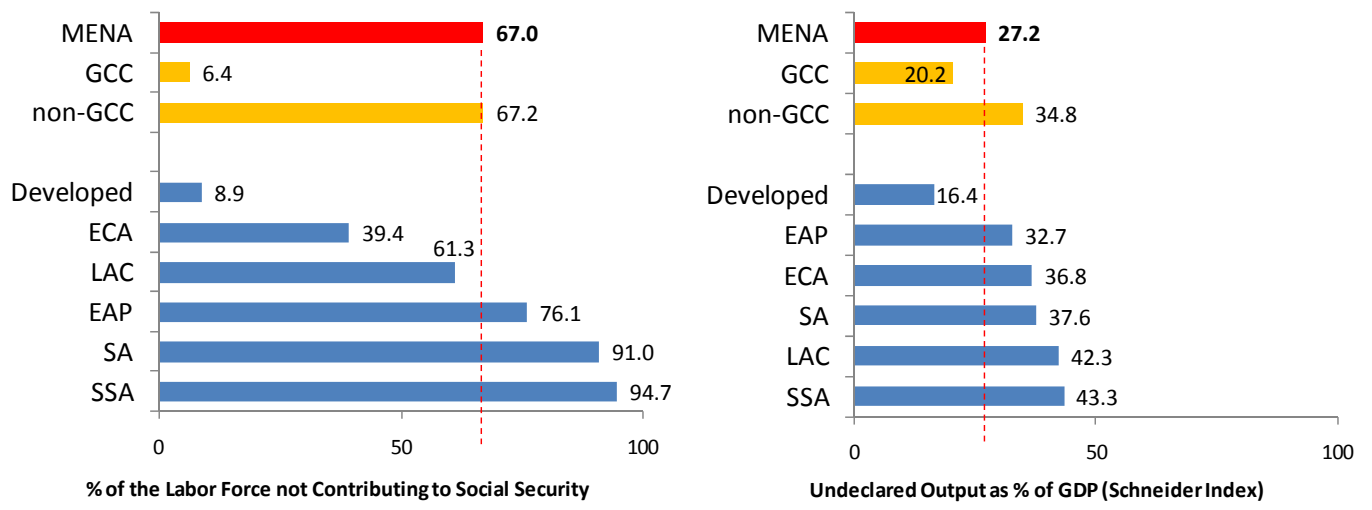

Source: Processed from Loayza and Wada (2010)

3. Despite its relevance, the phenomenon of informality in MENA has not been studied to a great extent. There is a significant knowledge gap when it comes to systematically understanding the main characteristics of the labor market in MENA countries, including informal employment. This occurs among others, because access to micro-survey data in the region is quite constrained due to strict 
confidentiality guidelines enforced by most national statistics bureaus in the region. Therefore, the use of micro-surveys (such as labor force surveys, consumption and expenditure surveys, and household budget surveys) remains very limited among researchers, academics, NGOs, and even public institutions. Indeed, MENA is the world region with the lowest number of publications in the field of labor markets (Angel-Urdinola, Hilger, and Irvins, 2010). Nevertheless, there are some available studies in the topic of informal employment in Egypt, Syria, Iraq, and Morocco. Most of these country-case studies concur in documenting a rapid increase in labor informality since the early 1980 s due to (i) a rapid increase in the growth of the labor force, (ii) accelerated urbanization, (iii) a contraction in public sector employment, and (iv) institutional constraints for establishing new businesses (see Wahba, 2009 and 2009a).

4. Recent studies have focused on the relationship between informal employment and demographic transition, public sector employment, and regulation. The informal sector in many MENA countries used to be seen as temporary employment for new entrants queuing for formal jobs. Wahba (2009a) finds that informal employment in Egypt, for instance, constitutes an important entry point for highly educated male workers. Nevertheless, informal employment has increasingly become (even for some educated individuals) a permanent state of employment associated with low pay, poor working condition, and limited mobility to formal sector jobs. Rodman (2007) argues that one of main reasons for the raise of informal employment in MENA is the decline in public sector employment as a share of total employment. ${ }^{2}$ Rodman also argues that formal business in many MENA countries face important challenges that restrain their capacity to grow, such as dealing with complex bureaucratic procedures; access to poor infrastructure, credit, technologies; and high labor taxes. A recent private sector assessment in Morocco, for instance, identifies that excessive regulation on the labor market has pushed much of the economic activity into informal sector (World Bank, 1999). Wahba (2009a) argues that declining fertility and mortality coupled with the increasing share of the youth population who attain tertiary education (notably among women) are also important factors contributing to the expansion of informal sector. Moreover, in some MENA countries, like Iraq, informality has been increasing considerably due to the effect of the recent armed conflict (Looney 2006).

5. Analysis in this note focuses on non-GCC countries, where informal employment is widespread and associated with precarious employment quality. It is important to note that the behavior of labor informality in the MENA differs highly between Gulf Corporation Council (GCC) countries and non-GCC countries. Labor informality in GCC countries, as proxied by the share of the labor force not contributing to social security is rather low at 6.4 percent. At the same time, informal employment in GCC countries produces about 20.2 percent of total GDP. This result indicates informal workers in GCC countries (mainly self employed workers) display high levels of productivity as their contribution to total economic output is larger than their share to overall employment. This generally occurs when workers choose to operate in the informal sector in order to achieve greater profit margins as they evade taxes, procedures, and are subject to less red tape in their operations. On the contrary,

\footnotetext{
${ }^{2}$ Labor markets in many MENA countries are still influenced by a legacy of a large public sector, which still accounts for about $29 \%$ of overall employment in the Arab World (Elbadawi and Loayza, 2008). The existence of a large public sector, still associated with generous benefits and better employment quality, creates an important segmentation between public and private employment (World Bank, 2010). At the same time, the private sector in many MENA countries is primarily composed of small and medium enterprises (SMEs), which account for about $95 \%$ of all registered enterprises. The great majority of SMEs in MENA has fewer than five workers and is characterized by high levels of informality; low involvement of women; concentration in low-growth sectors; low use of modern technologies; and a low level of product quality, competitiveness, diversification, and innovation (Stevenson, 2010). The share of overall private formal employment, for instance, is below 5 percent of overall employment in countries like Syria, Yemen, and Morocco.
} 
informal employment non-GCC countries is large (at 67.2 percent of the overall labor force) and produces only little output relative to their employment share (at 35 percent of GDP), suggesting very low levels of worker productivity in the informal sector. This generally occurs when informal workers are constrained from access to credit, services (such as utilities), and technology. The note provides analysis for a selected group of non-GCC countries, where informality (although a fairly heterogeneous phenomenon) is likely to be associated with an important prevalence of low-quality low-pay employment amongst a significant share of the overall labor force. ${ }^{3}$

6. Non-GCC countries included in this note are quite heterogeneous in terms of size, economic development, and demographic structure. Analysis in this note uses available micro-data from Egypt, Iraq, Lebanon, Morocco, Syria, Jordan, and Yemen (see Table 1). Each of these countries has important economic and demographic factors that are likely to affect the level and behavior of informal employment. As presented in Table 1, our study includes lower middle-income countries, like Yemen, Egypt, Morocco, and Syria; upper middle-income countries, like Lebanon and Jordan; and conflict affected countries, like Iraq. There are important variation across these countries: some of them are still very rural and agricultural employment still constitutes close to half of overall employment (Yemen and Morocco); some countries have a more educated workers (Egypt, Lebanon, and Jordan); and in some of the public sector still constitutes a significant share of overall employment (Egypt, Yemen, Iraq, and Syria). We believe that the heterogeneity in the sample of which countries included in the analysis will provide a broader perspective that is representative of the challenges of informal employment in the region.

Table 1: Economic and Demographic Factors [countries included in the analysis]

\begin{tabular}{|c|c|c|c|c|c|c|}
\hline & $\begin{array}{l}\text { GDP Per capita } \\
\text { (2000 US\$ } \\
\text { constant) }\left(^{*}\right)\end{array}$ & $\begin{array}{c}\% \\
\text { Employment } \\
\text { in Rural Areas }\end{array}$ & $\begin{array}{c}\% \\
\text { Employment } \\
\text { age 15-24 }\left({ }^{*}\right)\end{array}$ & $\begin{array}{c}\% \\
\text { Employment } \\
\text { in the Public } \\
\text { Sector }\end{array}$ & $\begin{array}{c}\% \\
\text { Employment } \\
\text { with University } \\
\text { education }\end{array}$ & $\begin{array}{c}\% \\
\text { Unemployment } \\
(*)\end{array}$ \\
\hline Egypt & 1785.83 & - & 23.1 & 30.0 & 16.8 & 8.7 \\
\hline Iraq & 730.79 & 27.1 & 23.2 & 36.9 & 12.8 & 17.5 \\
\hline Jordan & 2244.83 & 17.1 & 21.5 & 35.6 & 25.8 & 12.7 \\
\hline Lebanon & 5858.76 & - & 28.7 & 13.5 & 17.2 & 9.0 \\
\hline Morocco & 1718.14 & 43.5 & 34.7 & 19.2 & $8.7^{* *}$ & 9.6 \\
\hline Syria & 1329.85 & 49.6 & 32.3 & 26.8 & 7.4 & 8.4 \\
\hline Yemen & 559.97 & 71.8 & 21.9 & 38.6 & 5.4 & 15.0 \\
\hline
\end{tabular}

Source: Household surveys for available years.

Note: *World Development Indicators (WDI) dataset - last available year 1999-2008. ** WDI for 2006.

7. Results in this note indicate the size of the public sector and the size of the agriculture Sector are perhaps the strongest correlates of informality in the MENA region. Countries where agricultural employment still constitutes a large share of overall employment (such as Morocco and Yemen) are associated with higher levels of overall informality. On the contrary, countries with larger public sectors and more urbanized such as Egypt, Syria, and Lebanon, are associated with lower levels of overall

\footnotetext{
${ }^{3}$ As argued by Perry and others. (2007), there is considerable evidence suggesting that the informal sector is fairly heterogeneous, with workers/firms that have been excluded from the formal economy coexisting with others that have opted out on the basis of implicit cost benefit analysis. This latter concept of "exit" posits that at least some of those in the informal sector are there as a matter of choice. Specifically, some workers and firms, upon making some implicit or explicit assessment of the benefits and costs of formality, choose to opt out of the formal sector. Given existing opportunities and constraints, they actually prefer informality. Since there is a wide range of degrees to which exit or exclusion holds in any economy, these two perspectives are complementary characterizations rather than competing hypotheses.
} 
informality. Age, gender, and education also constitute important determinants of formality. Informality rates are generally highest among youngsters between ages 15 and 24 - a group that in most countries in the sample account for 24 to 35 percent of total employment. After age twenty-four, informality decreases rapidly until individuals reach prime working age (forty to forty-five years). This rapid decrease in informality rates goes hand in hand with a rapid increase in public sector employment, suggesting that informal workers enter into public sector jobs as they move from youth into adulthood.

8. Returns to education are very low in the informal sector. Estimates using standard wage regressions indicate that returns to education among workers in the informal sector are generally very low. As such, having to rely on informal sector jobs could constitute an important loss of human capital for young educated entrants, especially under an environment where mobility between the formal and informal sector is restricted and slow. For instance, a worker in the formal sector in Egypt who has completed 5 years of education (equivalent to primary education) earns similar wage-rates to those of a worker in the informal sector who has attained 12 to 14 years of education (equivalent to complete secondary and some post secondary education). On the contrary, returns to investments in secondary and tertiary education are quite significant in the formal sector. A typical formal worker in Egypt and Yemen with no experience but with 12 to 16 years of education (equivalent to complete secondary and tertiary education respectively) would earn wages-rates that are twice to three times larger than those earned by a formal worker with only 5 years of education (equivalent to primary education).

9. This note is structures as follows. Section 2 describes the data and the definitions used to proxy for informal employment; section 3 presents a profile of informal employment and the determinants of informality using a simple regression model; section 4 quantifies differences in returns to education between formal and informal workers using simple Mincerian wage equations. A brief conclusion follows.

\section{Data and Definitions}

10. Although the term "the informal economy" has been very widely used, there is no consensus on how to define it and/or measure it. In general terms, the informal sector is broadly defined as the collection of firms, workers, and activities that operate outside the legal and regulatory frameworks. The reality is that different types of informality co-exist and not a single definition is likely to be a selfcontained characterization of the sector. Indeed, Informality is a heterogeneous concept, encompassing different situations such as the unregistered small firm, the street vendor, and the large registered firm that employs a share of its workers without a written contract. The term "informal sector" was first used to refer to the "urban labor force working outside the formal labor market" in the context of developing countries (see Gerxhani, 2004). The usage of the term was operationalized by focusing on "all categories of (small) self-employed individuals". In subsequent years, ILO enlarged this definition in which informality was characterized by avoidance of government regulations and taxes (De Soto, 1989).

11. There are three main lenses through which informality can be studied: firms, workers, and untaxed activities:

- Firms: According to this definition, all individuals who work in small unregistered enterprises, both employers and employees, as well as self-employed persons who work in their own or family businesses, belong to the informal sector. A generally accepted definition of firm 
informality was proposed by the Delhi Group in 1997. According to their definition, the informal sector includes: private unincorporated enterprises (or quasi unincorporated) that produce at least some of their goods and services for sale or barter, have less than 5 paid employees, are not registered, and are engaged in non-agricultural activities (ILO 2002). Studies generally measure informality at the firm level through a direct (micro) measurement based on individual surveys, such as the World Bank's Enterprise Surveys, which explicitly ask the firm's owner or manager the year when the firm started its operations and the year the firm was legally registered. A discrepancy between the two is typically considered as the time when the firm operated informally (Angel-Urdinola and others, 2009).

- Workers: According to this definition, the informal sector is proxied by informal employment in informal enterprises (small unregistered or unincorporated) including employers, employees, own-account workers, and unpaid family workers; and informal employment in formal enterprises (domestic workers, casual or day laborers, temporary or part-time workers, industrial outworkers - including home workers - and unregistered or undeclared workers) (ILO 2002). ${ }^{4}$ The 17th International Conference of Labor Statisticians (ICLS) defined informal employment as the total number of informal jobs ${ }^{5}$, whether carried out in formal sector enterprises, informal sector enterprises, or households.

- Untaxed Activities: From a fiscal point of view, a large informal sector constitutes a set of activities that are "hidden" for tax purposes. The System of National Accounts distinguishes between four types of such activities: (i) Informal activities, which are undertaken to meet basic needs; (ii) underground activities, which are deliberately concealed from public authorities to avoid either the payment of taxes or compliance with certain regulations (e.g. most cases of tax evasion and benefit fraud); (iii) illegal activities, which generate goods and services forbidden by the law or which are unlawful when carried out by unauthorized producers; and (iv) household activities, which produce goods and services for own-consumption. There are several ways to measure the share of untaxed revenues: (i) tax audits to determine the percentage of the firms audited that evaded taxes and quantifies the amount of tax underreporting as informal activity, (ii) estimating the size of the informal economy as the difference between aggregate income and aggregate expenditure from the National Accounts, (iii) calculating the Multiple IndicatorMultiple Cause (MIMIC) model, popularized by Schneider (2004) to estimate of the size of the informal sector as a share of GDP.

\section{Measuring Labor Informality}

12. This note prioritizes on the relationship between informal employment and social protection. The social protection system in most MENA countries has historically been based on Bismarckian principles, whereby pension, health, and disability benefits are linked to employment in the formal sector. Nearly all MENA countries are characterized by what have been called "truncated welfare

\footnotetext{
${ }^{4}$ Own-account workers are those workers who, working on their own account or with one or more partners, hold the type of job defined as a self- employed job, and have not engaged on a continuous basis any employees to work for them during the reference period. (ILO 1993)

${ }^{5}$ Informal jobs are characterized by an employment relationship which is in law or in practice not subject to national labor legislation, income taxation, social protection or entitlement to certain employment benefits. Informal jobs include domestic work, casual or temporary works, industrial outwork, and jobs at unregistered or undeclared firms.
} 
systems." These are social protection systems in which formal sector actors employers and employees contribute to social security programs and have, in return, coverage for relatively generous, multidimensional benefit packages-often including health insurance, old-age pensions, disability and workers' insurance, and, in some cases, housing, child care, and sports and recreation benefits. Those outside the formal sector have had limited or no access to formal risk management instruments or other government benefits. At the same time, the size of non-contributory antipoverty and social protection programs, developed in more recent years, remains limited in scope and reaches, in most cases, a very narrow portion of society. In this context, informal employment could be used as a proxy to quantify workers' access to social protection in the region.

13. As such, in this note we measure informal employment is the share of overall employment that does not contribute to social security. There are many ways to measure informal employment such as (i) the share of unpaid employment, (ii) the share of self-employed as a share of total employment, (iii) the share of overall employment not contributing to social security (see Gasparini and Tornarolli, 2006 and Loayza and Rigolini, 2006); and (iv) the share of employees without a contract. In characterizing informal employment from the social protection side, a core definition relates to the absence of worker coverage by traditional social security programs-most notably health insurance and pensions, but often also other benefits available to workers by virtue of their labor contract (Perry and others, 2007). Figure 1 displays labor informality as percentage of total employment (urban and rural) using different definitions for Yemen, Morocco, Syria, Egypt, Jordan, Lebanon, and Iraq (see Table A1 in the annex for a detailed description of the data used for the analysis). Results indicate that the choice of labor informality measure matters (see Box 1 for definitions). If labor informality is measured by the share of unpaid workers to total employment, results in Figure 1 indicate great dispersion across countries. Since unpaid work is often associated with subsistence/family agricultural activities, the share of unpaid workers to total employment is often correlated with the size of agricultural employment as it is the case of Yemen and Morocco. If informal employment is measured by the share of selfemployment to total employment, results indicate less dispersion across countries with selfemployment accounting from 20 to 30 percent of overall employment, with the exception of Egypt and Jordan where self-employment accounts for less than 10 percent of overall employment. If informal employment is defined as the share of overall employment not contributing to social security, informality in MENA oscillates between 44 percent in Jordan and 91 percent in Morocco, suggesting that the majority of all workers are uncovered from old-age and health risks. ${ }^{6}$

\footnotetext{
${ }^{6}$ In all countries included in the analysis there is a positive correlation (oscillating between 0.17 in Yemen and 0.45 in Iraq) between being in self-employment and no contributing in social security and a positive correlation (oscillating between 0.10 in Lebanon and 0.40 in Yemen) between being unpaid worker and not contributing in social security. At the same time, in all countries included in the sample, there is a negative correlation between being unpaid worker and being self-employed (oscillating between -0.11 on Lebanon and -0.51 in Yemen). This indicates that not contributing in social security captures some of the aspects of informality faced by both unpaid workers and self-employed, which are two very different groups. Correlations are available upon request.
} 
Figure 1: Labor Informality as \% of Total Employment [Alternative Definitions]

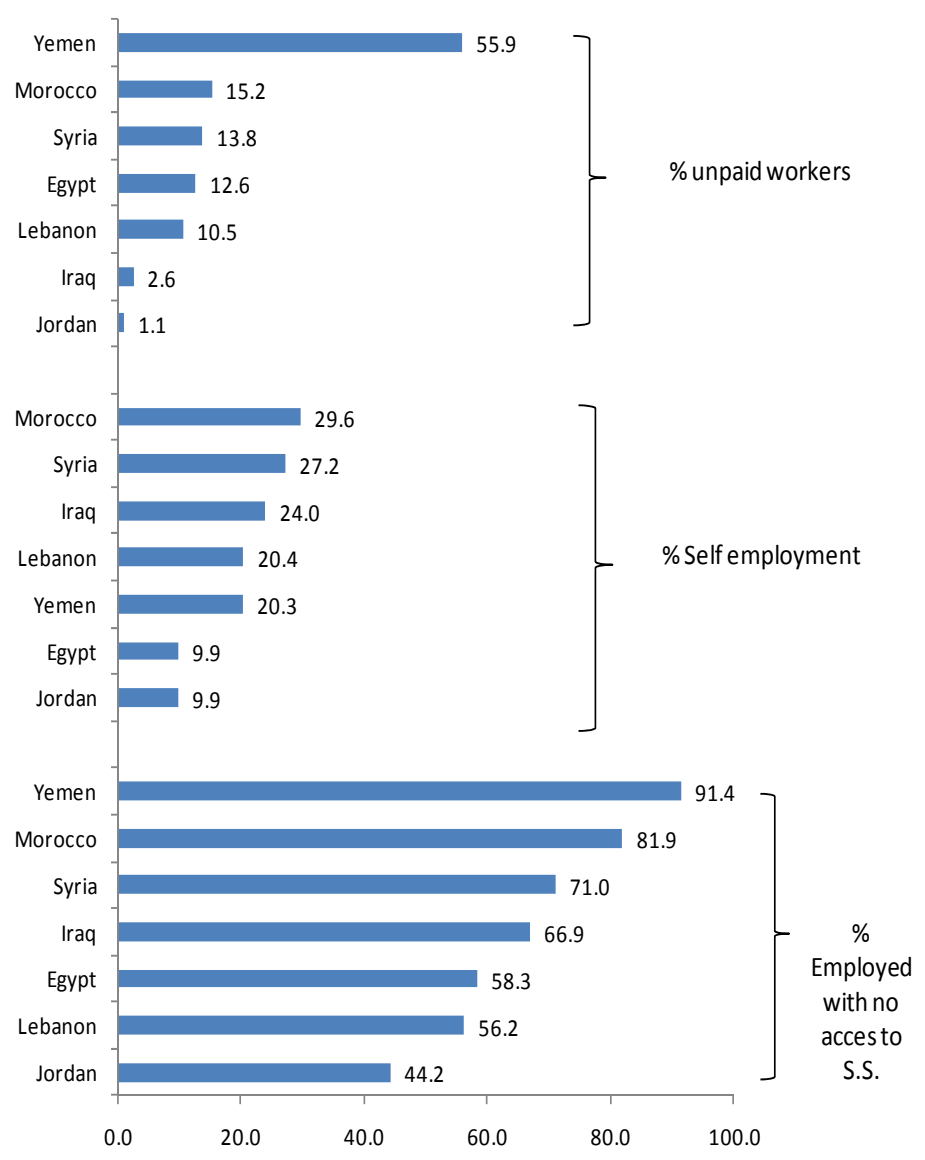

Source: Author's own estimates

14. In some countries such as Morocco and Yemen, access to social security is a privilege even among the richest segments of the population. Informality is a fundamental characteristic of underdevelopment. As such, informality generally decreases as wealth increases. Nevertheless, in some MENA countries, informal employment is substantial even among the wealthier segments of the population. In Yemen and Morocco, for instance, more than two-thirds of all workers who belong to the richest households work in the informal sector. In Lebanon, results are somehow more positive as expected, given that Lebanon is a wealthier country. In Lebanon, even among workers living in poor households, formal employment oscillates between 18 and 30 percent (which surpasses that of the richest workers in Yemen) (Figure 2). 
Figure 2: Informality rates of per capita consumption for selected countries

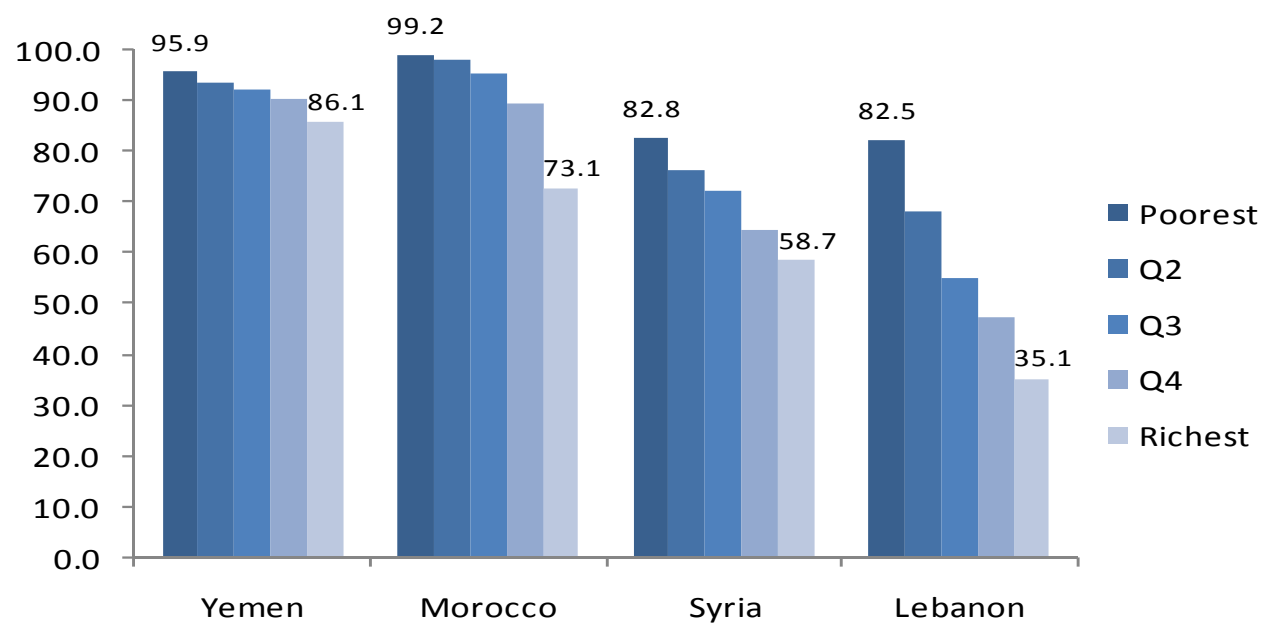

Source: Author's own elaboration.

Note: Consumption aggregate was not available for Morocco for 2010 at the time of completion of this report. Hence in this table, data for Morocco is from 2001 LSMS.

\begin{tabular}{|c|c|c|c|c|}
\hline \multirow[t]{3}{*}{$\begin{array}{l}\text { ox 1: Main Definitions and Labo } \\
\text { - } \quad \text { Working age population ( } \\
\text { Employed are those indiv } \\
\text { monetary for at least on } \\
\text { absence for education or } \\
\text { - } 2 \text { Informal workers are tho } \\
\text { social security. In differe } \\
\text { define informal workers: } \\
\text { pension and medical ben } \\
\text { 1=member; } 2=\text { beneficiar } \\
\text { and Jordan: Do you hav } \\
\text { health insurance); Yemer } \\
\text { only } 29 \% \text { have health ir } \\
\text { security includes pension } \\
\text { (source: } 1=\text { National secur } \\
\text { 5=private insurance at en } \\
\text { committee). } \\
\text { INDICATOR } \\
\text { Labor Force Part. Rate (\%) }\end{array}$} & \multicolumn{4}{|c|}{$\begin{array}{l}\text { Market Indicators } \\
\text { NAP) is composed by individuals in the age group } 15 \text { to } 64 \text { years old } \\
\text { duals in the WAP who satisfy any of the following conditions: (1) the person did } \\
\text { hour during the previous week (with a remuneration that could have been } \\
\text { he person was "temporarily absent" from work because of holidays, illness, paid } \\
\text { raining, maternity leave, strike, work dispute, seasonally work, etc. } \\
\text { e individuals in the WAP who are employed and do not make contributions to } \\
\text { it countries, depending on data availability, different questions were used to } \\
\text { Iraq: Is this job included in retirement systems and social security? (SS includes } \\
\text { fits); Morocco: What is your status as regards the social and medical security? } \\
\text {; } 3=\text { not covered (social security and medical insurance comes together); Egypt } \\
\text { social security? (Almost all people who have social security are covered by } \\
\text { : Benefit offered this job? (Pension) (Among those covered by pension system, } \\
\text { surance); Syria: Covered by social security or insurance and salaries? (Social } \\
\text { and medical benefits); Lebanon: is worker benefiting from health insurance? Yes } \\
\text { ty fund; } 2=\text { Government employees; } 3=a r m y \text { and security forces; } 4=\text { municipality; } \\
\text { ployer's expense; } 7=\text { mutual fund; } 8=\text { private through an institution, syndicate, or }\end{array}$} \\
\hline & Calculation & & & Description \\
\hline & $L F(U+E)$ & & & $\begin{array}{l}\text { Share of working age } \\
\text { population in the labor } \\
\text { market }\end{array}$ \\
\hline Employment Rate (\%) & & & & $\begin{array}{l}\text { Share of employed in the } \\
\text { working age population }\end{array}$ \\
\hline Unemployment Rate (\%) & & & $\begin{array}{l}\mathrm{LF} \\
(U+E)\end{array}$ & $\begin{array}{l}\text { Share of unemployed in the } \\
\text { labor force }\end{array}$ \\
\hline
\end{tabular}




\section{Profile and Determinants of Informality}

15. This section presents the profile of informal employment for the countries included in the analysis. The profile consists in a set of statistics describing the share of workers in the informal sector according to various characteristics, such as their level of education, age, gender, strata, marital status, and occupation among others. Since the public sector is the main source of formal employment in many of the countries included in the analysis, this note presents the informality profile for all workers in the sample (including the public sector) and for private sector workers only. Also, the analysis includes urban and rural workers. Many informality studies (see Perry and others, 2007) exclude rural employment from the analysis since it is mainly informal. This is not necessarily the case in MENA since there is an important presence of the public sector (and thus, of formal employment) in rural areas. While rural employment remains more informal than urban employment, informality rates in both rural and urban areas are somehow comparable and the relationship of informality and personal characteristics (such as age, gender, and years education) behaves rather similarly (Table 3) (more details of the profile for each country are included in the annex).

Table 3: Informality Rates for Selected Countries

\begin{tabular}{l|ccc}
\hline & All workers & $\begin{array}{c}\text { Urban } \\
\text { workers }\end{array}$ & $\begin{array}{c}\text { Rural } \\
\text { Workers }\end{array}$ \\
\hline Egypt & 58.3 & 42.6 & 70.0 \\
Lebanon & 56.2 & 48.3 & 66.7 \\
Iraq & 66.9 & 63.5 & 76.1 \\
Syria & 71.0 & 65.9 & 76.3 \\
Yemen & 91.4 & 84.7 & 94.0 \\
Morocco & 81.9 & 72.7 & 93.8 \\
Jordan & 44.2 & 47.5 & 28.3 \\
\hline
\end{tabular}

Source: Author's own elaboration.

16. Age, gender, and education constitute important correlates of informality. Figure 3 presents a basic set of correlations between informal employment and individual characteristics such as age, gender, and years of education. Not surprisingly, results indicate that age and education are negatively associated with informality (i.e. more age and education are associated with less informality). The size of the correlation between years of education and informality is large for all countries (oscillating between -0.27 in Jordan and -0.47 in Syria), suggesting important decreases in informal employment as the country's level of education increases. On the contrary, the magnitude of the correlation between age and informality varies across countries and strata. For instance, the negative association between age and informality seems larger in Iraq, Yemen, Syria, and Morocco than in Egypt, Jordan, and Lebanon and generally stronger in urban than in rural areas. 


\section{Figure 3: Basic Correlations by Strata [Informality and Individual's Characteristics]}

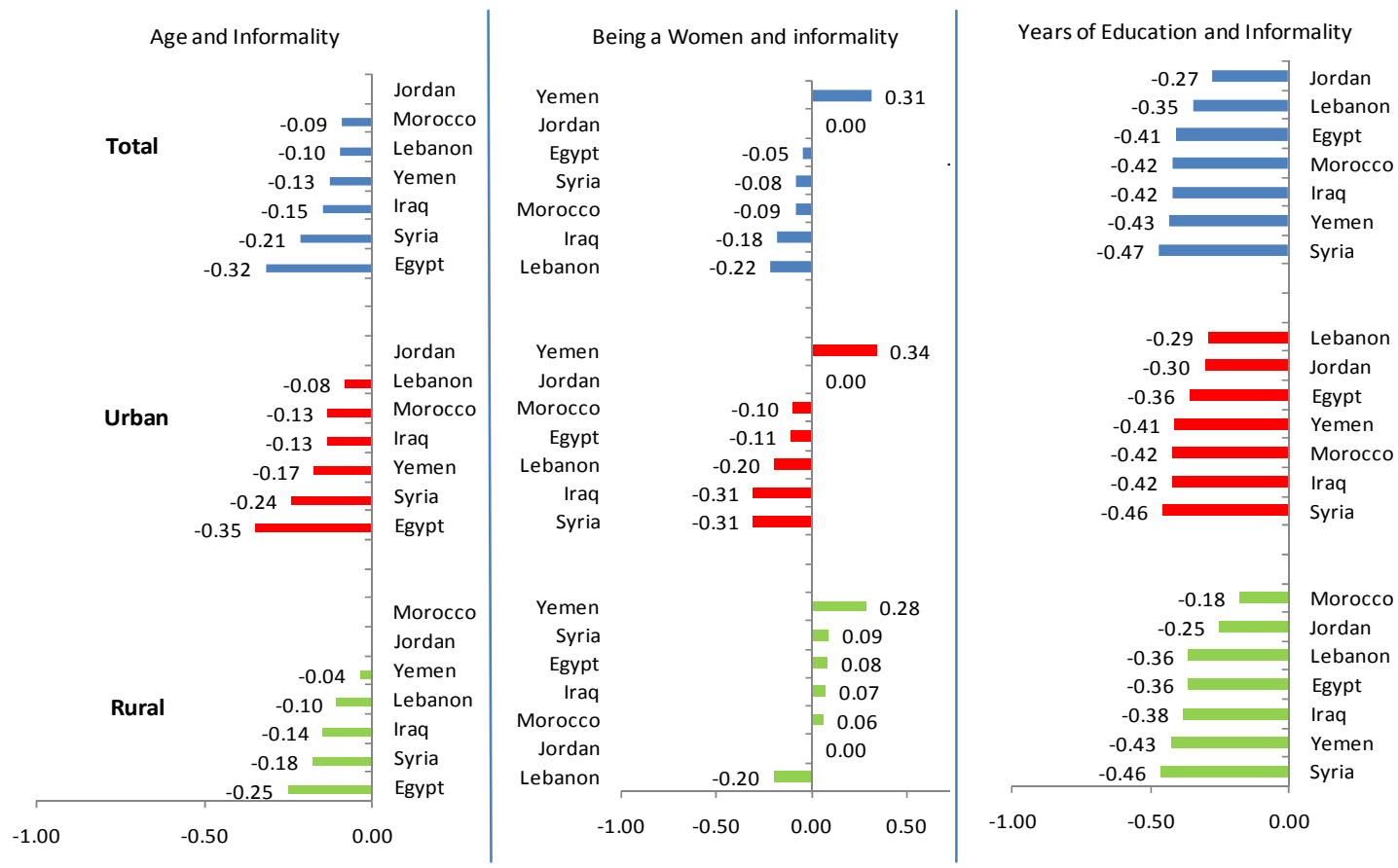

Source: Author's own elaboration.

17. Being a woman is associated with higher informality rates in some countries and with lower informality rates in others. As illustrated in Figure 3, the correlation between being a woman and working in the informal sector varies across countries and strata. In countries where agricultural employment constitutes an important share of overall employment, like Yemen, being a woman is associated with higher levels of informality since women are often employed in unpaid/subsistence agriculture. In countries where public employment constitutes a significant share of overall employment like Egypt, Iraq, and Syria, being a woman is associated with lower levels of informality. Given low overall levels of female participation, women in these countries who participate in the labor force - generally those with higher levels of education - tend to select themselves into public sector jobs.

18. The relationship between education attainment and informal employment is less pronounced for workers in the private sector. Informality rates among workers who attained primary and/or basic education (which account for at least 50 percent of overall employment in most countries in the region) are generally much higher than among workers who attained secondary vocational and/or tertiary education. Differences in informality rates by age and education are less pronounced for workers in the private sector. Indeed, in some countries like Yemen and Iraq, differences in informality rates by age and educational attainment for workers in the private sector are almost negligible (Figure 4). 


\section{Figure 4: Informality Rates by Highest Education Level Completed}
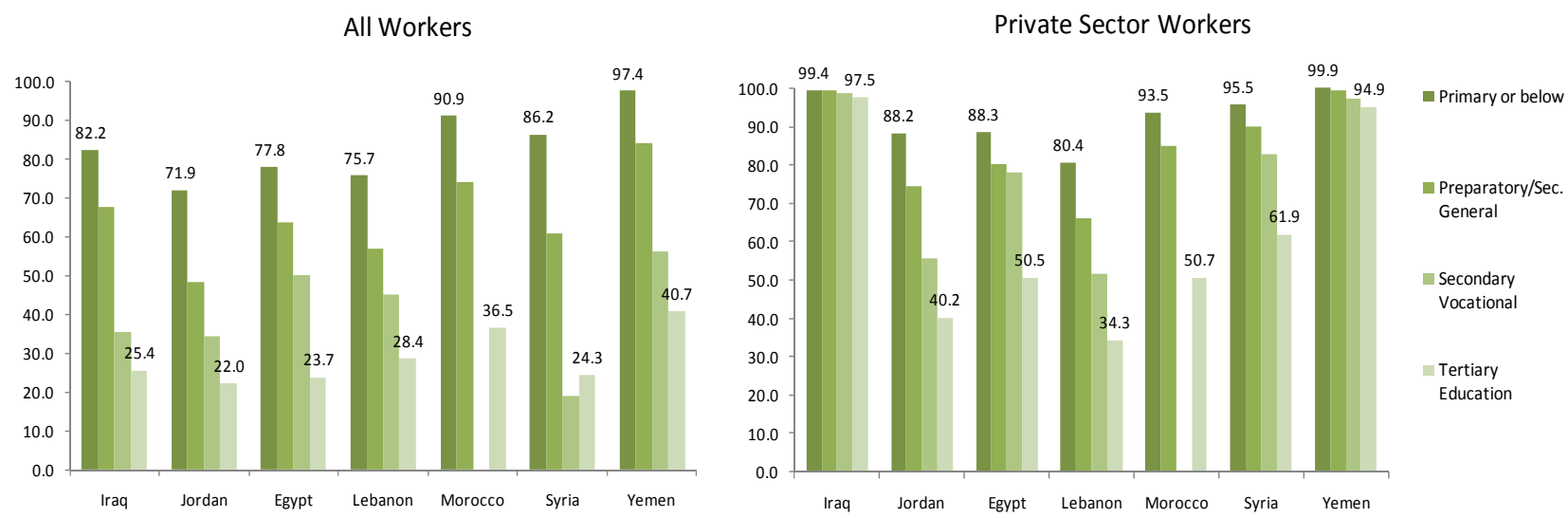

Source: Author's own elaboration

19. In most countries in the region, public sector employment accounts for the majority of all formal employment. Civil service in many MENA countries is larger than in other countries with similar levels of income and economic structure. Historically, in countries like Egypt, the growth in the civil service was the result of a social contract in the 1970s and 1980s whereby the government effectively offered employment guarantees to university graduates, and to graduates of vocational secondary schools and training institutes. Despite the fact that employment growth in the public sector has slowed dramatically in recent years, public sector employment still accounts for the majority of all formal sector employment. ${ }^{7}$ In some countries, like Yemen and Iraq, formal employment is almost entirely associated with public employment. In other countries, the public sector remains a main engine of formal employment: in Egypt about 45 percent of all new formal jobs (about 260,000) created in the economy between 1998 and 2006 were in the public sector (Angel-Urdinola and Semlali, 2010). Given the weight of the public sector in overall formal employment, changes in the size of the public sector are likely to affect overall informality trends, especially given that formal private employment growth remains limited. In particular, the creation of formal private sector jobs has not been sufficient to offset the downsizing of the public sector in many countries (Rodman, 2007), explaining the raising trends in informality in some countries in the region.

20. There is an important transition from informal employment into public sector employment as young individuals reach prime age adulthood. Figure 5 illustrates employment patterns by age for urban workers in a selected group of countries. Informality rates are very high among youth between ages fifteen and twenty-four. After age twenty-four, informality decreases rapidly to 20 to 30 percent as individuals reach prime working age (forty to forty-five years). This rapid decrease in informality rates goes hand in hand with a rapid increase in public sector employment, suggesting that informal workers enter into public sector jobs as they move from youth into adulthood. Not surprisingly, many individuals in the region queue in the informal sector until they find a job in the public administration. These trends are very different from those observed in Latin America. In Mexico, for instance, while informality rates

\footnotetext{
${ }^{7}$ Results using available household surveys indicate that the public sector accounts for $57.3 \%$ of all formal employment in Morocco, 63\% in Jordan, 68.1\% in Egypt, $70.4 \%$ in Lebanon, 83\% in Syria, $97 \%$ in Yemen, and $98 \%$ in Iraq.
} 
also decrease by age, the observed transition occurs not between informality and public employment, but between informality and self-employment (Perry et al., 2007).

Figure 5: Employment status by age for selected countries, urban areas only
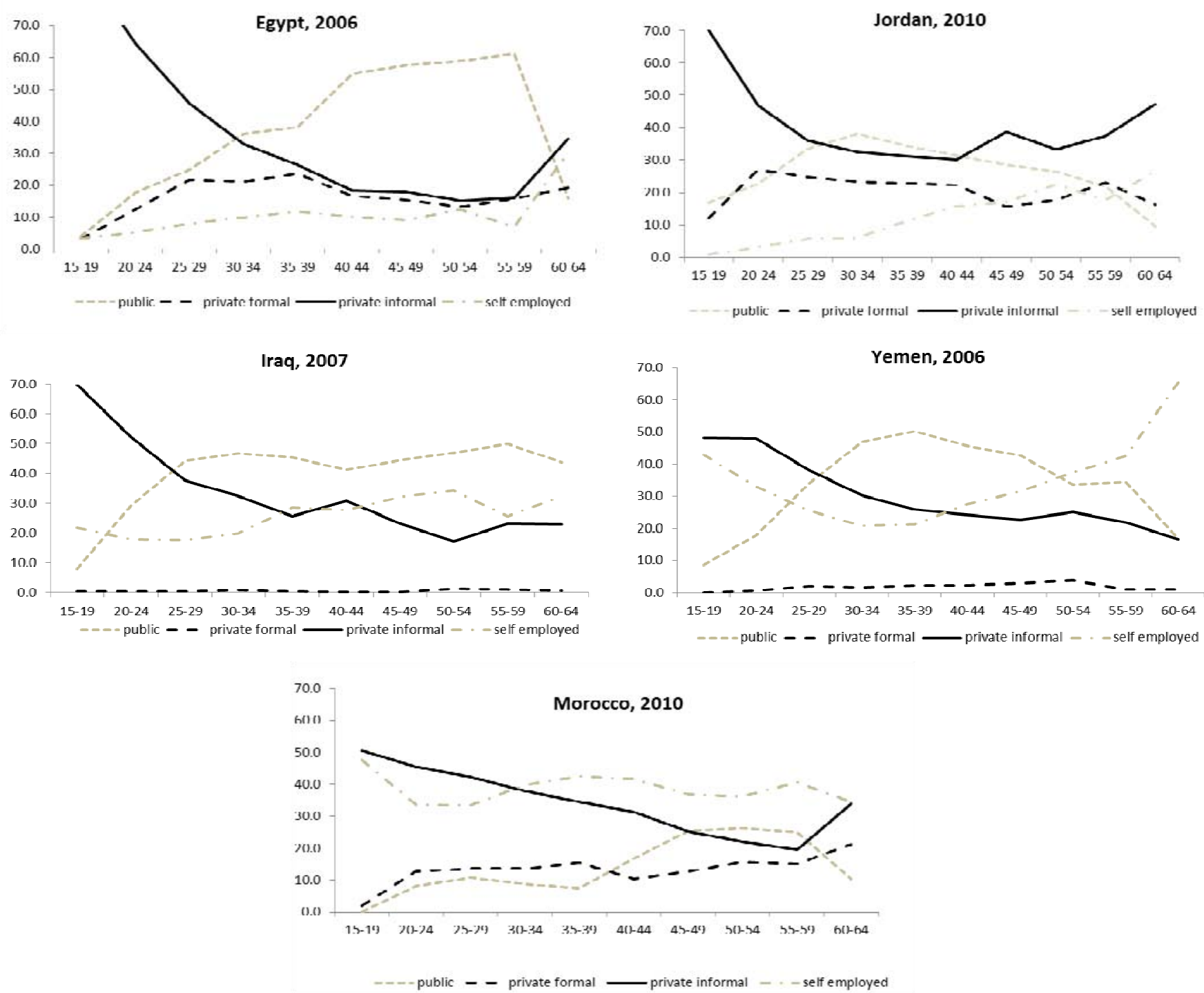

Source: Authors' own elaboration

21. Informality rates are generally higher for workers in the primary sector and among selfemployed workers. Results indicate that informality rates among self-employed workers (which account between 5 and 35 percent of all employment for most countries in the analysis) are quite high, oscillating between 80 percent in Lebanon to almost 100 percent in Iraq and Yemen (Table 4). Since the promotion of self-employment/micro-entrepreneurship continues to be a core strategy for many countries in the region to boost employment creation, new, flexible, and innovative mechanisms to assure pension and social security coverage for the self-employed should be developed and implemented. Results also indicate that 40 to 80 percent of all wage earners (which account for 40 to 72 
percent of overall employment in all countries, except in Yemen) work in the informal sector. ${ }^{8}$ In relation to sector of employment, results indicate that the great majority of workers in agriculture/mining activities (which account for as little as 5 percent of all workers in Iraq and for as much as 50 percent in Morocco) work in the informal sector. Among workers employed in public administration/social services; which in countries like Egypt, Iraq, Syria and Yemen account for as much as one third of all employed workers; informality rates are below 20 percent. This is probably explained by the existence of fix-term contracts in the public sector.

Table 4: Informality Rates by Employment Status and Sector of Employment

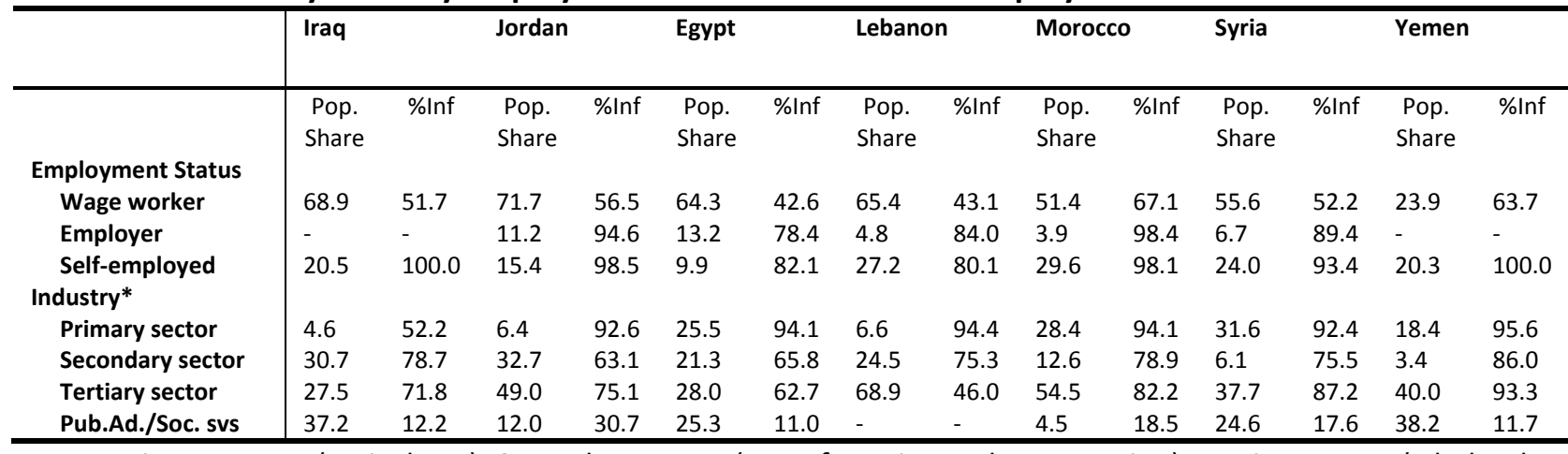

Note: Primary sector (agriculture); Secondary sector (manufacturing and construction); Tertiary sector (wholesale, transport, services), Public administration and social services (including education and health)

\section{Determinants of Informality}

22. While a profile of informality is informative, the main drawback is that it cannot be used to disentangle its determinants. For example, the fact that a group of workers (e.g., agricultural workers) displays high rates of informality may be due in large part to other characteristics of the group (e.g., the educational level of the group's members). To provide more insights about the determinants or correlates of informality, this section assesses informality through regression analysis using a simple probit regression model. The dependent variable of the regression model is a binary variable that takes a value of one if the worker is employed in the informal sector (i.e., if the worker does not contribute to social security) and zero otherwise. Separate regressions are provided for the full sample and for workers in the non-agricultural sector. ${ }^{9}$ The main independent variables used include: (i) strata (an urban dummy); (ii) demographic characteristics of the worker (a male dummy, a married dummy, and the worker's age group); (iii) the highest educational level attained by the worker; (iv) employment status and sector of the worker; and ( $v$ ) ownership of the firm where the worker is employed (using a dummy for publicly owned firms). As these are cross-sectional regressions, results should not be interpreted causally.

\footnotetext{
${ }^{8}$ In Yemen, 56 percent of all workers are employed in unpaid agriculture, 20 percent are self-employed, and the remaining 24 percent are wage earners (the lowest share in the region).

${ }^{9}$ Results including agricultural employment are very similar to those presented in the chapter and are available upon request.
} 


\section{The main results are summarized as follows:}

- Strata: In many countries, especially in Latin America (see Perry et al., 2007) rural employment is mainly associated with informal agricultural activities. In MENA countries, this is not necessarily the case, since there is an important public sector presence (and thus, of formal employment) in rural areas. Controlling for other factors, urban workers are only 3 to 12 percent less likely to be employed informally than otherwise similar workers in rural areas in Egypt and Lebanon. In Iraq, Morocco, and Yemen, the difference in the probability of workers' formality between urban and rural areas is small and/or not statistically significant (Table 5).

- Gender: the effect of being male on the probability of working in a formal job varies across countries (see Figure 6 and Table 5). In Egypt and Morocco, controlling for other factors, being a male worker is associated with a 4 to 12 percent lower probability of being employed informally as is generally the case in many developing countries (see Perry et al., 2007 for estimates from Latin America). On the contrary, in Iraq, Lebanon, Jordan, and Syria, being male is actually associated with a 6 to 17 percent higher probability of working in the informal sector. This result is probably due to the fact that female workers (generally educated ones) who participate in the labor force tend to queue for formal jobs in the public sector (Angel-Urdinola and Semlali, 2010). In Yemen, gender does not seem to be an important determinant of informal employment.

Figure 6: Marginal increase in the probability of being informal according to gender and marital status (in \%)

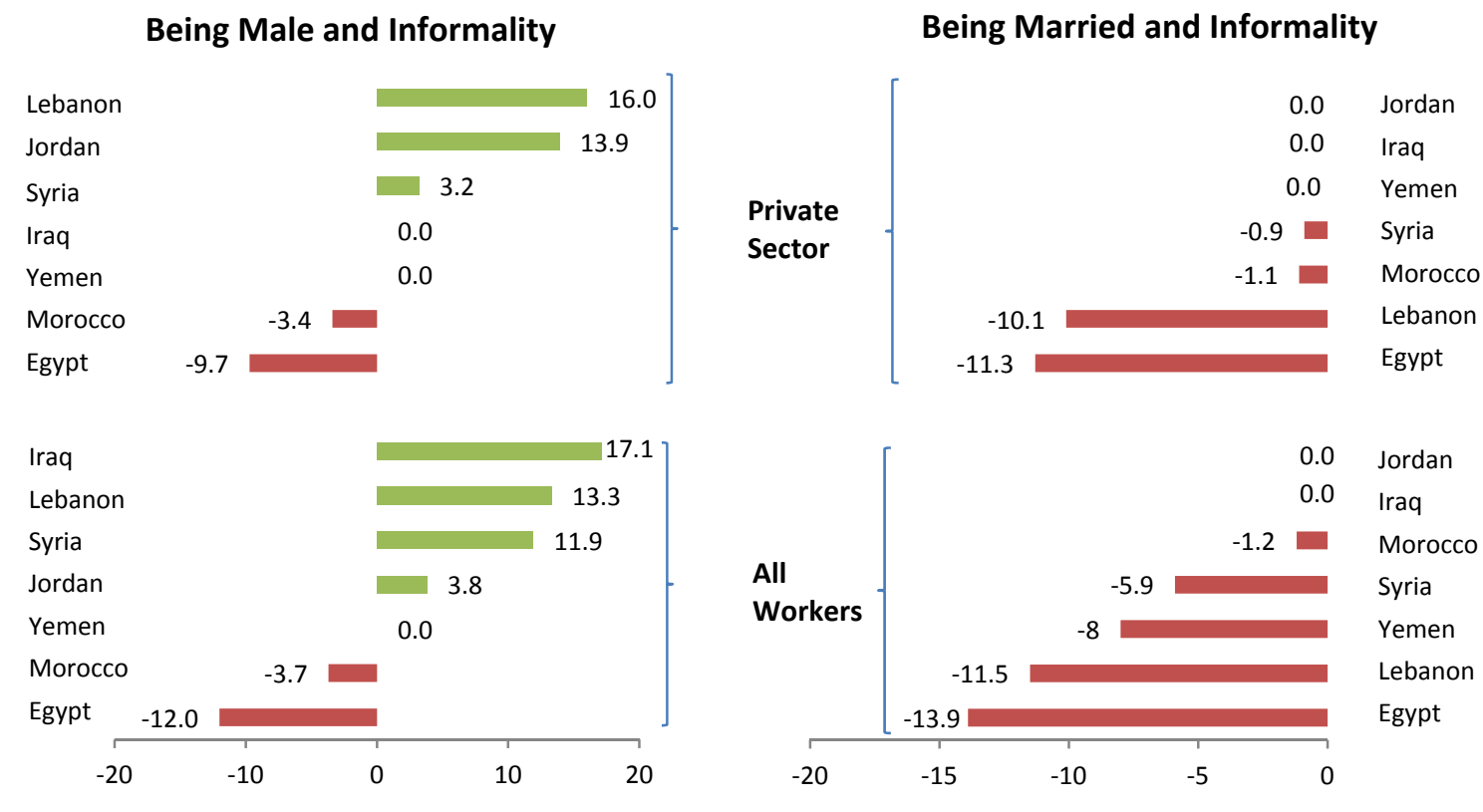

Source: Author's own elaboration.

- Marital status: In the MENA region, there are important associations between marriage and labor outcomes. Recent literature shows that having good and stable employment is an important social requirement for individuals, especially young men, to get married. These results are consistent with the findings herein, as being married, controlling for other factors, is associated with a 10 to 14 percent lower probability of working in the informal sector in Egypt 
and Lebanon, and a 2 to 8 percent lower probability in Morocco, Yemen, and Syria (see Figure 6 and Table 5). In Jordan, marital status is not significantly associated with informal employment.

- Age: Controlling for other factors, younger workers are more likely to work in the informal sector (Table 5). Results from Egypt, Yemen, and Syria indicate that adults thirty-five and older are 13 to 34 percent less likely to work in the informal sector than youth aged fifteen to twentyfour. In Iraq, Lebanon, Jordan, and Morocco, the association between age and informality is less strong, since adults twenty-five and older are only 2 to 8 percent less likely to work in the informal sector than youth aged fifteen to twenty-four. It is worth noting that acquiring informal jobs is a way for young individuals to enter the labor market, gain experience, and eventually move into formal employment, as informality decreases quickly with age. The effect of age on informality is generally lower in magnitude for private sector workers. This is expected since the private sector in MENA remains largely informal. To better illustrate this phenomenon, Figure 7 shows informality rates by age for men and women for Syria and Egypt. Results in the left panel show that informality rates decrease rapidly as age increases up to age forty to forty-five and increases again thereafter as individuals retire. Results also indicate that early retirement is quite common, especially among women. In the private sector (shown in the right panel of Figure 7), informality rates by age are rather flat and high, especially for women, suggesting that the negative slope between age and informality is driven by workers entering public sector employment as they reach prime working age, as discussed earlier.

Figure 7: Informality rates by age group (Egypt and Syria)

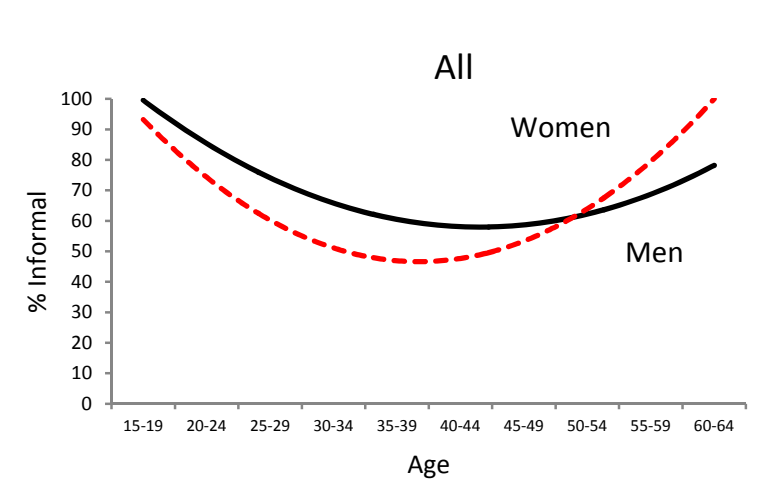

Syria

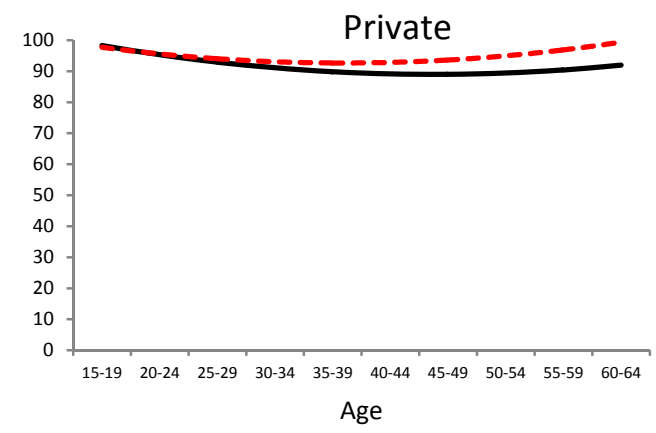

Egypt
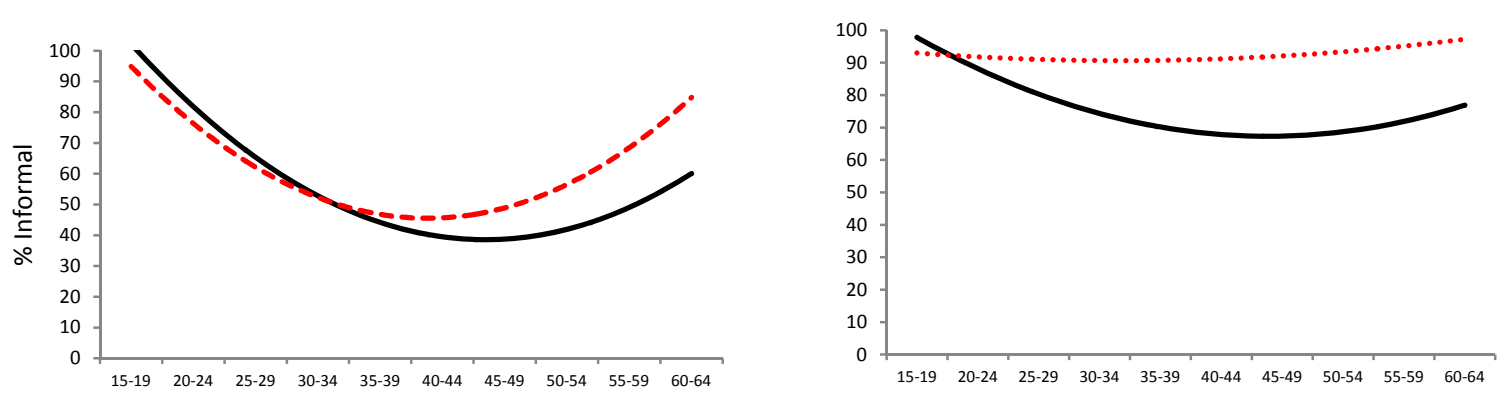

Source: Author's own elaboration. 
- Highest educational level attained: Controlling for other factors, more education is associated with a lower probability of being employed in the informal sector. The negative relationship between attaining higher education and having a lower probability of being employed informally is much lower for private sector workers (confirming the results presented in the profile of informality). Controlling for other characteristics, attaining middle school (high-school) is associated with a 5 to 18 (12 to 37) percent lower probability of working in the informal sector compared to otherwise similar workers who attained at most primary school. Attaining tertiary education is associated with up to a 47 percent lower probability of being employed informally compared to otherwise similar workers who attained at most primary school. In some countries (e.g., Iraq, Syria, and Yemen), having completed high school decreases the probability of workers being employed informally as much as (or even more than) having attained tertiary education, which is an interesting results.

Table 5: Marginal increase in the probability of being "informal" according to the characteristics of the worker (non-agricultural employment only)

\begin{tabular}{|c|c|c|c|c|c|c|c|c|c|c|c|c|c|c|}
\hline \multirow{2}{*}{$\begin{array}{l}\text { Dependent } \\
\text { variable: } \\
\text { Informal } \\
\text { Employment }\end{array}$} & \multicolumn{2}{|c|}{ Egypt } & \multicolumn{2}{|c|}{ Iraq } & \multicolumn{2}{|c|}{ Yemen } & \multicolumn{2}{|c|}{ Lebanon } & \multicolumn{2}{|c|}{ Syria } & \multicolumn{2}{|c|}{ Morocco } & \multicolumn{2}{|c|}{ Jordan } \\
\hline & All & Priv. & All & Priv. & All & Priv. & All & Priv. & All & Priv. & All & Priv. & All & Priv. \\
\hline Urban dummy & -9.5 & -8.0 & N.S. & N.S. & N.S. & -1.8 & -13.5 & -12.1 & 4.1 & 1.8 & -2.3 & -1.5 & N.S. & N.S. \\
\hline Male dummy & -12.0 & -9.7 & 17.1 & 5.5 & N.S. & N.S. & 13.3 & 16.0 & 11.9 & 3.2 & -3.7 & -3.4 & 3.8 & 13.9 \\
\hline Married & -13.9 & -11.3 & N.S. & N.S. & -8.0 & N.S. & -11.5 & -10.1 & -5.9 & -0.9 & -1.2 & -1.1 & N.S. & N.S. \\
\hline \multicolumn{15}{|l|}{ Age Group } \\
\hline $25-34$ & -12.9 & -10.3 & -7.6 & N.S. & -16.1 & -1.7 & -5.7 & -6.2 & -26.9 & -4.8 & -2.6 & -1.9 & -4.7 & N.S. \\
\hline $35-54$ & -29.2 & -23.3 & -12.7 & -1.5 & -26.2 & -4.7 & -12.4 & -12.5 & -33.8 & -7.4 & -3.3 & -2.3 & N.S. & N.S. \\
\hline $55-64$ & -30.3 & -35.9 & -24.3 & N.S. & -20.2 & N.S. & -15.3 & -15.4 & -36.4 & -9.6 & -3.2 & -2.1 & N.S. & 15.5 \\
\hline \multicolumn{15}{|l|}{ Education } \\
\hline Middle School & -11.0 & -10.4 & -8.8 & N.S. & -17.5 & -2.5 & -14.6 & -12.2 & -12.1 & -4.5 & N.S. & N.S. & -10.0 & -16.7 \\
\hline High School & -17.1 & -15.0 & -22.7 & -2.1 & -26.7 & N.S. & -25.7 & -25.4 & -27.4 & -7.9 & -14.4 & -11.5 & -15.4 & -36.9 \\
\hline Tertiary & -25.2 & -33.7 & -25.3 & N.S. & -19.9 & -6.6 & -33.2 & -37.2 & -31.8 & -17.7 & -21.6 & -20.6 & -17.9 & -46.6 \\
\hline \multicolumn{15}{|l|}{ Sector } \\
\hline Tertiary sector* & -4.6 & -3.8 & N.S. & N.S. & 25.1 & 3.7 & -13.1 & -10.7 & 23.9 & 11.8 & 4.7 & 4.0 & 12.4 & 18.2 \\
\hline $\begin{array}{l}\text { Pub. Ad.\& Soc.S } \\
\text { versus** }\end{array}$ & -11.1 & -11.1 & -14.2 & -7.7 & N.S. & N.S. & - & - & - & - & -5.8 & -6.4 & -9.7 & -11.7 \\
\hline \multicolumn{15}{|l|}{ Ownership } \\
\hline Public firm & -59.4 & - & -82.4 & - & -80.7 & - & -52.8 & - & -74.6 & - & -33.3 & - & -48.8 & \\
\hline Observations & 8752 & 5244 & 12362 & 4361 & 8500 & 3939 & 13373 & 11254 & 32461 & 20471 & 6500 & 6252 & 4441 & 2237 \\
\hline
\end{tabular}

Source: Author's own elaboration.

Notes: (All) All workers (Priv.) Private sector workers. All coefficients are multiplied by 100 . Coefficients that are not statistically significant are denoted by N.S. Underlined coefficients are significant at a 10 percent confidence level. Other coefficients are significant at a 5 percent confidence level. Omitted categories: Age group: 15-25; Education: Primary education or below. Employment Sector: Secondary sector (manufacturing and construction); Ownership: private firms. *Tertiary sector (wholesale, transport, services) **Public administration and social services (including education and health).

- Sector of employment: Controlling for other factors, the association between informality and sector of employment varies across countries. In countries where the tertiary sector is more developed towards high value-added services such as financial services, transport, tourism, and communications (e.g., in Egypt and Lebanon), workers in the tertiary sector are associated with a 4 to 13 percent lower probability of working informally compared to workers in the secondary sector (i.e., manufacturing and construction). On the contrary, in countries where the tertiary sector is mainly geared towards low-value added personal services and wholesale/retail (e.g., in 
Yemen and Syria) workers in the tertiary sector are associated with a 4 to 25 percent higher probability of working informally compared to workers in the secondary sector. Workers in public administration and social services are associated with 6 to 14 percent lower informality rates than otherwise similar workers in the secondary sector.

- Public sector employment: Controlling for other factors, this variable is perhaps the most important determinant of informality. In all countries where information about firm ownership is available, workers in the public sector are associated with a 30 to 85 percent higher probability of working formally compared to otherwise similar workers in the private sectors (Table 5).

- Firm size: Data on firm size were only available for a few countries in the region (namely Egypt, Iraq, Jordan, and Morocco). For these countries, firm size dummy variables are included in the regression analysis (small size firm dummy, fewer than ten workers; medium size firm dummy, ten to fifty workers; and large size firm dummy, more than fifty workers). Regression coefficients are shown in Figure 8; the results indicate an important association between informality and firm size. Workers in medium size (large size) firms are 16 to 21 (17 to 53) percent less likely to work in the informal sector compared to workers in small size firms.

Figure 8: Marginal increase in the probability of being "informal" according to firm size (in \%) (Omitted category, small firms, 2-9 workers)

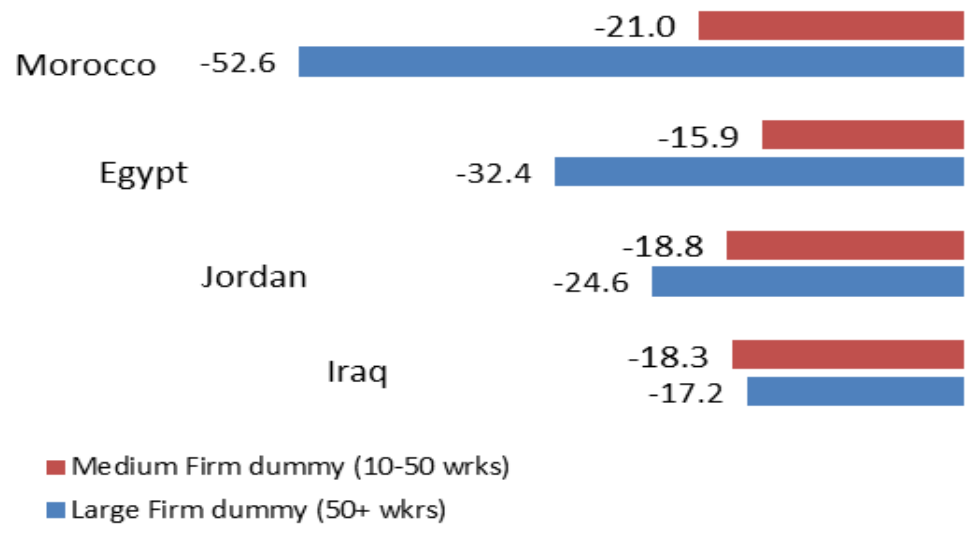

Source: Author's own elaboration.

\section{Informality and Human Capital Formation}

24. Data available in Egypt and Yemen provide useful information on net hourly wages. Of all the data sources used in the study, data on wages were only available in Yemen and Egypt. These data are useful to assess returns to education for workers in the informal sector vis a vis those in the formal sector. Doing so allows estimating the impact of informality in human capital formation. To avoid a strong selection bias, the analysis that follows is restricted to those individuals living in urban areas that are wage earners and work full time (between 30 and 60 hours a week). Table 6 provides descriptive statistics on average hourly wage rates (in local currency) by educational attainment, gender, age group, and sector of employment for workers in the public, private formal, and private informal sectors. 
25. Wages in the informal sector are generally lower than in the formal sector. Results in Table 6 show that average wages in the informal sector are generally lower than in the formal sector for most age, education, and gender groups. Wages are highest in the formal private sector (composed mainly by large companies and multinationals). Somehow expected, wages are generally higher for more educated/more experienced workers and lower for workers in the agriculture sector. Also, wages for male workers are significantly higher than for female workers. Wages can also be assessed by looking at the whole distribution using Kernel density plots (Figure 12). In Egypt, the distribution of wages for workers in the formal sector (public and private formal) stochastically dominates that of workers in the informal sector (i.e. the distribution of wages for informal workers is to the left of that of formal workers at all points in the wage distribution). In Yemen, this is not the case. Indeed, at the right tale of the wage distribution, there is a small mass of informal-private workers earning higher wages than formal workers in the public sector. ${ }^{10}$

Table 6: Average hourly wages in local currency [Yemen and Egypt]

\begin{tabular}{|c|c|c|c|c|c|c|}
\hline & Public & $\begin{array}{l}\text { Private } \\
\text { formal }\end{array}$ & $\begin{array}{l}\text { Private } \\
\text { informal }\end{array}$ & Public & $\begin{array}{l}\text { Private } \\
\text { formal }\end{array}$ & $\begin{array}{l}\text { Private } \\
\text { informal }\end{array}$ \\
\hline & & YEMEN & & & EGYP & \\
\hline \multicolumn{7}{|l|}{ Educational Attainment } \\
\hline Primary and below & 104.48 & 111.12 & 148.35 & 3.31 & 2.95 & 2.32 \\
\hline Preparatory/Sec. Gen. & 140.25 & 229.12 & 149.51 & 3.33 & 2.87 & 2.26 \\
\hline Sec. Vocational & 129.22 & 142.14 & 114.34 & 3.52 & 3.20 & 2.19 \\
\hline University and above & 198.46 & 296.52 & 222.62 & 5.22 & 8.27 & 3.13 \\
\hline \multicolumn{7}{|l|}{ Gender } \\
\hline Female & 124.01 & 207.55 & 69.93 & 2.83 & 2.68 & 1.37 \\
\hline Male & 158.42 & 219.80 & 164.45 & 3.03 & 3.25 & 2.08 \\
\hline \multicolumn{7}{|l|}{ Age Group } \\
\hline $15-24$ & 87.70 & 74.32 & 124.06 & 2.76 & 2.68 & 1.78 \\
\hline $25-34$ & 136.04 & 182.49 & 161.16 & 3.54 & 5.27 & 2.66 \\
\hline $35-54$ & 184.26 & 248.48 & 196.94 & 4.32 & 5.55 & 2.85 \\
\hline $55-64$ & 163.63 & 367.91 & 181.51 & 5.65 & 8.37 & 2.69 \\
\hline \multicolumn{7}{|l|}{ Sector of Employment } \\
\hline Primary & 138.33 & 185.93 & 157.53 & 3.67 & 5.13 & 2.09 \\
\hline Secondary & 182.95 & 174.68 & 105.85 & 4.60 & 5.15 & 2.42 \\
\hline Tertiary & 161.47 & 237.40 & 170.24 & 5.08 & 5.88 & 2.41 \\
\hline Total Average & 154.48 & 218.87 & 158.03 & 4.21 & 5.29 & 2.39 \\
\hline
\end{tabular}

Source: Author's own elaboration. Sample: urban wage earners working between 30 and 60 hours per week. Primary sector (agriculture); Secondary sector (manufacturing and construction); and Tertiary sector (wholesale, transport, services).

26. Differences in wage rates by age, education, and employment sector are less pronounced in the informal sector. Descriptive statistics in Table 6 also indicate that male workers, workers with higher levels of education, and more experienced workers (proxied by age), display higher average wage rates. Also, workers in the secondary and tertiary sectors display on average higher wage rates than workers in the primary sector. While these results are somehow expected, important differences arise in the trends describing on whether workers are employed in the formal or in the informal sector. Results indicate

\footnotetext{
${ }^{10}$ Since formal workers are required to pay taxes, some high-earning workers have the incentive to evade taxes and get higher net wages, especially if they have access to health insurance (though a family member) and/or to pension (as it is the case of some private consultants who have retired from the formal sector).
} 
that in the formal sector, wage rates among university graduates are 2 to 3 times higher than those among worker who have attained only primary education. To a similar extent, more experienced workers in the formal sector (i.e. those in the oldest age group) earn wage rates that are 2 to 3 times higher than those of the least experienced workers (i.e. those in the youngest age group). In the informal sector, differences in wage rates by age and education attainment are less pronounced, which provides some prima-facie evidence that returns to education and experience are lower for workers employed in the informal sector as compared to those working in the formal sector.

\section{Figure 9: Kernel Density Plots of Hourly Wages by Employment Sector}
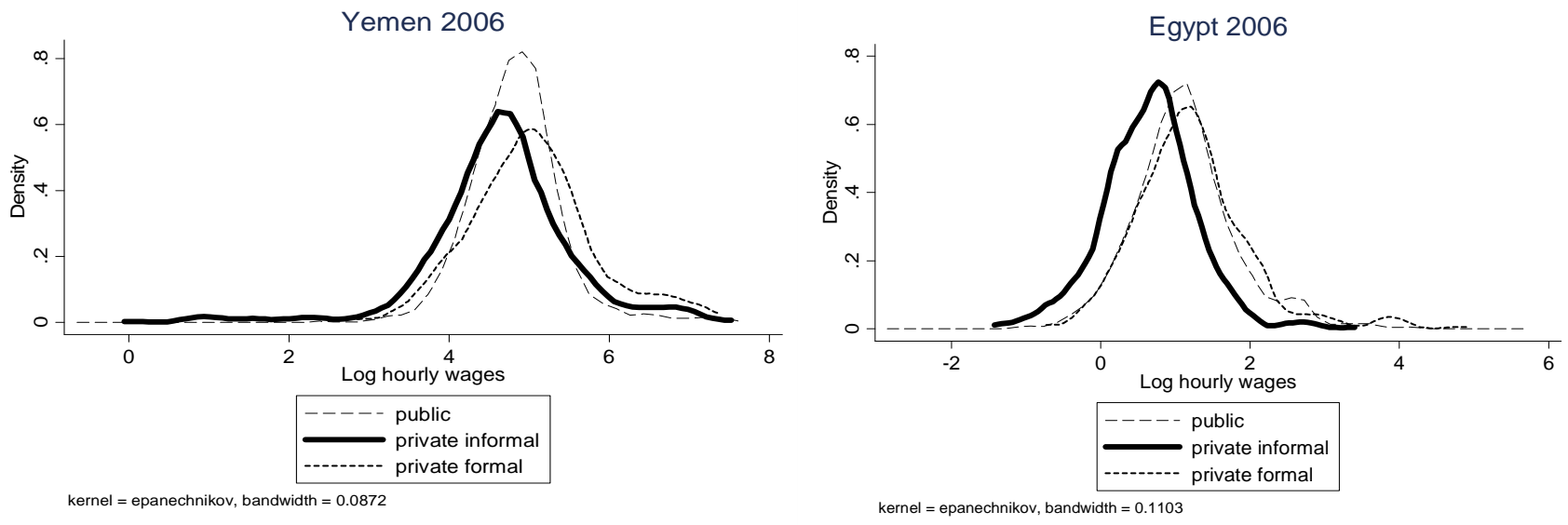

Source: Author's own elaboration.

Human Capital Formation

27. Returns to education in the informal sector are very low. Table 7 presents the coefficients of Mincer equations using OLS regressions for the sample of urban wage earners working full time (between 30 and 60 hours per week) using data from Yemen and Egypt. ${ }^{11}$ Specification (1) includes all workers in the sample and specifications (2), (3), and (4) limits the sample to workers in the public, formal private, and informal private sectors respectively. The model includes variables generally included in a standard human capital accumulation model (years of education, education level dummies, experience, experience squared, and a gender dummy). Since the dependent variable is in logarithms, the size of the coefficients cannot be interpreted directly. To simplify the interpretation, Figure 10 plots the expected wage rates of an average worker (with no experience) according to his/her years of education attained by applying the exponential function to the coefficients obtained from the Mincer model. ${ }^{12}$ Results indicate very clearly that returns to education (and especially of primary and secondary education) are very low in the informal sector.

\footnotetext{
${ }^{11}$ The exclusion of part time workers from the estimates of the Mincer equation allows us to reduce the sample selection problem due to differences in skills, gender, and labor supply patterns of part time workers.

12 There could be unobserved factors that determine the selection of workers into the formal/informal sectors. In order to address this potential selection bias, results of the Mincer model were verified using a Heckman selection model. Heckman's estimation was carried out in two steps. In the first stage, we estimated a consistent estimator of the probability of workers to be employed in the informal sector controlling for their age, gender, and education. In the second stage we corrected for self-selection by incorporating a transformation of these predicted individual probabilities as an additional explanatory variable. Heckman coefficients did not vary much from those obtained by the Mincer Model. Heckman estimates are available upon request.
} 
Table 7: Mincer Model of Wage Determination

\begin{tabular}{|c|c|c|c|c|c|c|c|c|}
\hline & \multicolumn{4}{|c|}{ Egypt 2006} & \multicolumn{4}{|c|}{ Yemen 2006} \\
\hline & (1) & (2) & (3) & (4) & (1) & (2) & (3) & (4) \\
\hline $\begin{array}{l}\text { Dependent variable = } \\
\text { log hourly wage }\end{array}$ & All & Public & $\begin{array}{l}\text { Private } \\
\text { formal }\end{array}$ & $\begin{array}{l}\text { Private } \\
\text { informal }\end{array}$ & All & Public & $\begin{array}{l}\text { Private } \\
\text { formal }\end{array}$ & $\begin{array}{l}\text { Private } \\
\text { informal }\end{array}$ \\
\hline Years of education * & 5.50 & 5.70 & 7.30 & 3.40 & 4.70 & 6.00 & 9.00 & 4.60 \\
\hline Experience ${ }^{*}$ & 3.80 & 3.70 & N.S. & $\underline{3.60}$ & 3.80 & 3.00 & 3.80 & 4.70 \\
\hline Experience squared * & 0.00 & 0.00 & N.S. & $\overline{0.00}$ & 0.00 & 0.00 & N.S. & -0.10 \\
\hline Male dummy * & 26.10 & 18.80 & 40.20 & 51.70 & 39.40 & 15.60 & N.S. & 96.20 \\
\hline Constant & -0.46 & -0.44 & -0.42 & -0.51 & 3.48 & 3.53 & 3.13 & 2.92 \\
\hline Observations & 3238 & 2079 & 432 & 727 & 5065 & 2817 & 118 & 2126 \\
\hline R-squared & 0.22 & 0.19 & 0.19 & 0.16 & 0.16 & 0.28 & 0.30 & 0.13 \\
\hline
\end{tabular}

Source: Author's estimates. N.S: Not Significant. Underlined coefficients are significant at a 10 percent confidence level. All other coefficients are significant at 5 percent confidence level. * Coefficients $\times 100$.

Figure 10: Expected Wages by Years of Education Attained [Based on Mincer Model]

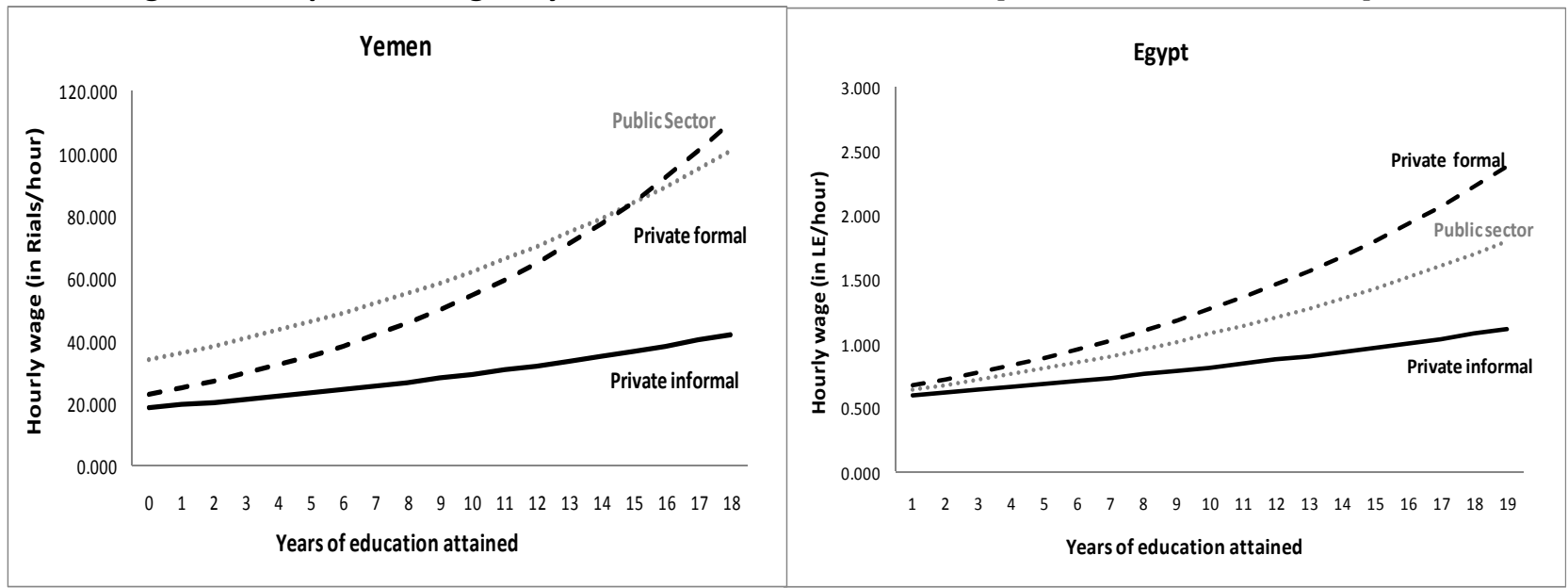

Source: Author's estimates. Expected wages are calculated using the following equation: $\mathrm{E}(\mathrm{w} \mid \mathrm{Yrs}$ of edu $)=$ $\exp \left(C+\beta_{1}\right.$ Yrs of Edu. $+\beta_{2}$ Experience $+\beta_{3}$ Experience squared $+\beta_{4}$ Male Dummy $)$

28. As such, having to rely on informal sector jobs may constitute an important loss of human capital for young entrants. Results in Figure 10 suggest that informal jobs - generally associated with low-wages - display low levels of productivity as compared to those in the formal sector. For instance, a worker in the informal sector in Egypt who has completed 5 years of education (equivalent to primary education) earns similar wage-rates to those of a worker in the informal who has attained 12 to 14 years of education (equivalent to complete secondary and some post secondary education). On the contrary, returns to investments in secondary and tertiary education are quite significant in the formal-private sector as well as in the public sector. For instance, a typical formal worker in Egypt and Yemen with no experience but with 12 to 16 years of education (equivalent to complete secondary and tertiary education respectively) would earn wages-rates that are twice to three times larger than those earned by a formal worker with 5 years of education (equivalent to primary education). There is a possible effect of unobserved innate ability that could be associated with a selection into informal sector; however, this is beyond the scope of this analysis. 


\section{Conclusions}

29. This note assesses the main micro-determinants of informal employment from a human development stand point. Some countries in the Middle East and North Africa (MENA) region are among the most informal economies in the world. The typical country in MENA produces about 27 percent of its GDP and employs 67 percent of its labor force informally. These are remarkable statistics, indicating than more than two thirds of all the workers in the region may not have access to health insurance and/or are not contributing to a pension system that would provide income security after retirement age. At the same time, about one third of total economic output in the region remains undeclared and therefore not registered for tax purposes. Furthermore, it indicates that informal sector workers are employed with jobs with the low productivity.

30. Contrary to other developing regions, patterns of urban and rural informality in MENA are somewhat similar, due to the presence of the public sector. Urban workers are only 5 to 12 percent less likely to be employed in the informal sector than otherwise similar workers in rural areas. Controlling for age and education, in some countries like Iraq, Morocco, and Yemen, there is not a difference in the probability of being employed in the informal sector does not vary across urban and rural workers.

31. The size of the public sector and the size of the agriculture Sector are perhaps the main determinants of informality in the MENA region. Countries in the MENA region are quite heterogeneous in terms of size, economic development, and demographic structure. Countries where agricultural employment still constitutes a large share of overall employment (such as Morocco and Yemen) are associated with higher levels of overall informality. On the contrary, countries with larger public sectors and more urbanized such as Egypt, Syria, and Lebanon, are associated with lower levels of overall informality. The existence of a large public sector, still associated with generous benefits and better employment quality, creates an important segmentation between public and private employment in many MENA countries. At the same time, the private sector in many MENA countries is primarily composed of small and medium enterprises (SMEs), which account for about $95 \%$ of all registered enterprises. In all countries where information about firm ownership is available, workers in the public sector are associated with a 45 to 80 percent lower probability to work informally as compared to otherwise similar workers in the private sectors. Self-employed workers as well as agricultural workers in most MENA countries are associated with a 10 to 20 percent higher likelihood of being employed informally as compared to otherwise similar workers employed as wage earners.

32. Age, gender, and education also constitute important determinants of formality. Informality rates are generally highest among youngsters between ages 15 and 24 - a group that in most countries in the sample account for 24 to 35 percent of total employment. After age 25, informality rates decrease rapidly in most countries. This rapid decrease in informality rates goes hand in hand with a rapid increase in public sector employment, suggesting that informal workers enter into public sector jobs as they move from youth into adulthood. Attaining secondary technical and tertiary education is associated with a 40 percent higher probability to be employed formally as compared to otherwise similar workers who attained at most primary school. The relationship between gender and informality varies across countries. In Egypt, controlling for other factors, being a male worker is associated with a 6 to 14 percent higher probability of being employed informally as women generally queue for formal sector jobs. On the contrary, In Iraq and Lebanon, being a male is actually associated with a lower probably of working in the informal sector as it is generally the case in many developing countries. 
33. Results indicate that the average worker in the informal sector is somehow disadvantaged versus the average worker in the formal sector, as they are uncovered against social risks and are generally employed in low-productivity/low pay jobs. Results indicate that returns to education are very low in the informal sector. As such, having to rely on informal sector jobs constitutes an important loss of human capital for young entrants. For instance, a worker in the informal sector in Egypt who has completed 5 years of education (equivalent to primary education) earns similar wage-rates to those of a worker in the informal who has attained 12 to 14 years of education (equivalent to complete secondary and some post secondary education). On the contrary, returns to investments in secondary and tertiary education are quite significant in the formal sector. A typical formal worker in Egypt and Yemen with no experience but with 12 to 16 years of education (equivalent to complete secondary and tertiary education respectively) would earn wages-rates that are twice to three times larger than those earned by a formal worker with only 5 years of education (equivalent to primary education).

\section{References}

Angel-Urdinola, D., Reis, J.G.,., and Quijada, C. (2009) Informality in Turkey: Size, Trends, Determinants and Consequences. Mimeo. World Bank, Washington D.C.

Angel-Urdinola, D., Hilger, A, and Ivins, I.(2010). Economic Incentives for Enhancing Data Access. Mimeo. The World Bank, Washington D.C.

De Soto, H. (1989). The Other Path: The Invisible Revolution in the Third World. New York, NY: HarperCollins.

Elbadawi, I., and Loayza, N.. (2008) Informality, Employment and Economic Development in the Arab World. Paper presented at International Conference on "The Unemployment Crisis in the Arab Countries" in Cairo. Mimeo. Washington D.C.

Gasparini, L., and Tornarolli, L. (2006). Labor Informality in Latin America and Caribbean: Patterns and Trends from Household Survey and Microdata. Mimemo. World Bank, Washington D.C.

Gerxhani, K.(1999). The Informal Sector in Developed and Less Developed Countries: A Literature Survey. Public Choice Vol. 120(3-4): 267-300.

ILO. (1993). Resolutions Concerning International Classification of Status in Employment Adopted by the 15th International Conference of Labour Statisticians, Geneva.

ILO (2002). Decent Work and the Informal Economy: Sixth Item on the Agenda. International Labour Conference. Geneva.

ILO. (2008). The Rights of Women Migrant Domestic Workers in Arab States: Policy and Regulatory Change in Lebanon, Gender Issue Brief 1, Beirut.

Loayza, N.and Rigolini, J. (2006). Informality Trends and Cycles. World Bank Policy Research Working Paper No. 4078. The World Bank, Washington D.C. 
Loayza, N.., and Wada, T. Informal Labor in the Middle East and North Africa: Basic Measures and Determinants. Mimeo. World Bank, Washington D.C.

Looney, R.(2006). Economic Consequences of Conflict: The Rise of Iraq's Informal Economy. Journal of Economic Issues, Vol. XL(4).

Perry, G., Maloney,W, Arias, O, Fajnzylber, P, Mason, A., and Saavedra-Chanduvi, J.(2007) Informality: Exit and Exclusion. World Bank, Washington, D.C.

Rodman, S. God Jobs, Bad Jobs, and Economic Performance: A View from the Middle East and North Africa Region, Employment and Shared Growth, edited by Pierella Pace and Pieter Serneels. World Bank, Washington D.C.

Schneider, F. (2004). The Size of the Shadow Economies of 145 Countries all over the World: First Results over the Period 1999 to 2003, IZA DP No. 1431. Bonn.

Stevenson, L. (2010). Understanding Entrepreneurship in MENA: Where to go next. A presentation notes for ICSB Global Entrepreneurship Summit. Washington D.C.

Wahba, J. (2000). Formal Testing of Informalization of Labor in Egypt: Has Informalization Increased in Egypt? Conference paper, International Centre for Economic Growth, Egypt Policy Institute Consortium Program. Cairo

Wahba, J. (2009). Labor Markets Performance and Migration Flows in Egypt. European University Institute, Firenze

Wahba, J.(2009a) The Impact of Labor Market Reforms on Informaltiy in Egypt. The Population Council, Cairo.

World Bank.(1999). Kingdom of Morocco: Private Sector Assessment Update. Report No. 19975-MOR, Washington D.C.

World Bank. (2004) Unlocking the Employment Potential in the Middle East and North Africa: Toward a New Social Contract. MENA Development Report, Washington D.C.

World Bank. (2005). Women in Local Economic Development-Aden. Report No. 32259-YEM. Washington D.C.

World Bank (2010). Doing Business 2010. Washington, DC. 


\section{ANNEX 1 Informality Profiles by Country}




\begin{tabular}{|l|l|}
\hline Egypt & $\begin{array}{l}\text { - } \\
\text { Data Source: Egypt Labor Market Survey } \\
2006\end{array}$ \\
\hline
\end{tabular}

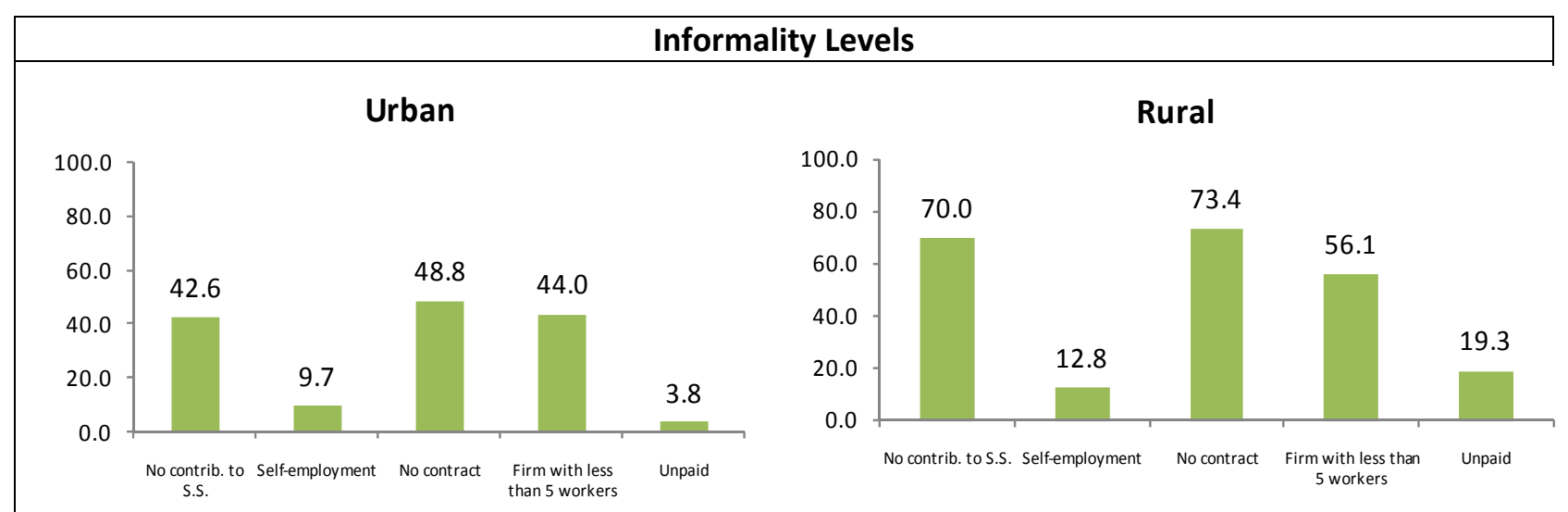

Definitions: No contributing to SS is \% of workers who do not contribute to social security; self-employment is \% of selfemployed in total employment; no contract is \% of workers without a written contract; and unpaid is \% of non-wage workers in total employment.

\begin{tabular}{|c|c|c|c|c|c|c|c|c|c|}
\hline \multicolumn{10}{|c|}{ Informality Profile } \\
\hline 100.0 & 87.1 & Age Grou & & \multirow[b]{3}{*}{51.2} & \multicolumn{5}{|c|}{ Educational Attainment } \\
\hline 80.0 & & \multirow{2}{*}{61.4} & \multirow{2}{*}{43.4} & & 100.0 & 77.8 & \multirow[b]{2}{*}{63.7} & \multirow[b]{2}{*}{50.0} & \multirow[b]{3}{*}{23.7} \\
\hline 60.0 & & & & & $\begin{array}{l}80.0 \\
60.0\end{array}$ & & & & \\
\hline 40.0 & & & & & 40.0 & & & & \\
\hline 20.0 & & & & & 20.0 & & & & \\
\hline & $15-24$ & $25-34$ & $35-54$ & $55-64$ & & Prim. and & Prep./Sec. & Sec. Voc. & Tertiary \\
\hline 100.0 & & Gender & & & 100.0 & 94.1 & Industr & & \\
\hline 80.0 & & 79 & & & 80.0 & & 65.8 & 62.7 & \\
\hline 60.0 & & & & & 60.0 & & & & \\
\hline 40.0 & & & & & 40.0 & & & & \\
\hline 20.0 & & & & & 20.0 & & & & 11.0 \\
\hline & & len & & & 0.0 & primary & secondary & tertiary & admn+soc.sv \\
\hline
\end{tabular}




\begin{tabular}{|c|c|c|c|}
\hline \multicolumn{4}{|c|}{ Informality Determinants } \\
\hline \multicolumn{4}{|c|}{ Marginal Increase in the Probability of being "informal" according to the characteristics of the worker } \\
\hline & \multicolumn{3}{|c|}{ All } \\
\hline & Total & Male & Female \\
\hline Urban dummy & -9.8 & -8.4 & -14.8 \\
\hline Male dummy & -14.7 & & \\
\hline Married & -11.4 & -11.6 & -11.6 \\
\hline \multicolumn{4}{|l|}{ Age Group (youth 15-24) } \\
\hline $25-34$ & -13.0 & -14.6 & N.S. \\
\hline $35-54$ & -30.4 & -31.0 & -30.7 \\
\hline $55-64$ & -37.5 & -38.7 & -33.2 \\
\hline \multicolumn{4}{|l|}{ Education (omitted: primary and below) } \\
\hline Preparatory/Sec. Gen. & -8.4 & -6.4 & -21.4 \\
\hline Sec. Vocational & -12.1 & -11.2 & -15.4 \\
\hline Tertiary & -14.3 & -16.2 & N.S. \\
\hline \multicolumn{4}{|c|}{ Occupation (omitted: elementary occupations) } \\
\hline Legislators/Officials/managers & -39.7 & -37.9 & -79.2 \\
\hline Professionals & -44.4 & -41.3 & -95.6 \\
\hline Technicians & -37.6 & -36.6 & -88.6 \\
\hline Clerks & -36.8 & -37.0 & -77.6 \\
\hline Service workers/salesmen & -24.4 & -25.4 & -82.1 \\
\hline Skilled agricultural/fishery worker & N.S. & 18.3 & -97.9 \\
\hline Craft and related trade workers & -11.8 & -10.9 & -71.4 \\
\hline Operators & -46.0 & -45.8 & N.S. \\
\hline \multicolumn{4}{|l|}{ Activity (omitted: primary sector) } \\
\hline Secondary sector & -10.1 & N.S. & -41.9 \\
\hline Tertiary sector & N.S. & N.S. & -36.5 \\
\hline Public adm.\&social service & -13.6 & N.S. & -31.0 \\
\hline \multicolumn{4}{|l|}{ Ownership if the firm (vs. private firms) } \\
\hline Public firms & -62.8 & -63.1 & -58.1 \\
\hline Observations & 11309 & 8699 & 2610 \\
\hline \multicolumn{4}{|c|}{$\begin{array}{l}\text { Note: Informality is proxied as \% of workers not contributing to social security. Coefficients } \\
\text { reported in the table are multiplied by } 100 \text {. Underlined coefficients are significant at a } 10 \text { percent } \\
\text { confidence level. N.S is not significant. Other coefficients are significant at a } 5 \text { percent confidence } \\
\text { level. }\end{array}$} \\
\hline
\end{tabular}




\begin{tabular}{|l|l|}
\hline Iraq & $\begin{array}{l}\text { Data Source: Iraq Household Socio- } \\
\text { Economic Survey } 2007\end{array}$ \\
\hline
\end{tabular}

\begin{tabular}{|l|l|}
\hline & Informality Levels \\
\hline
\end{tabular}

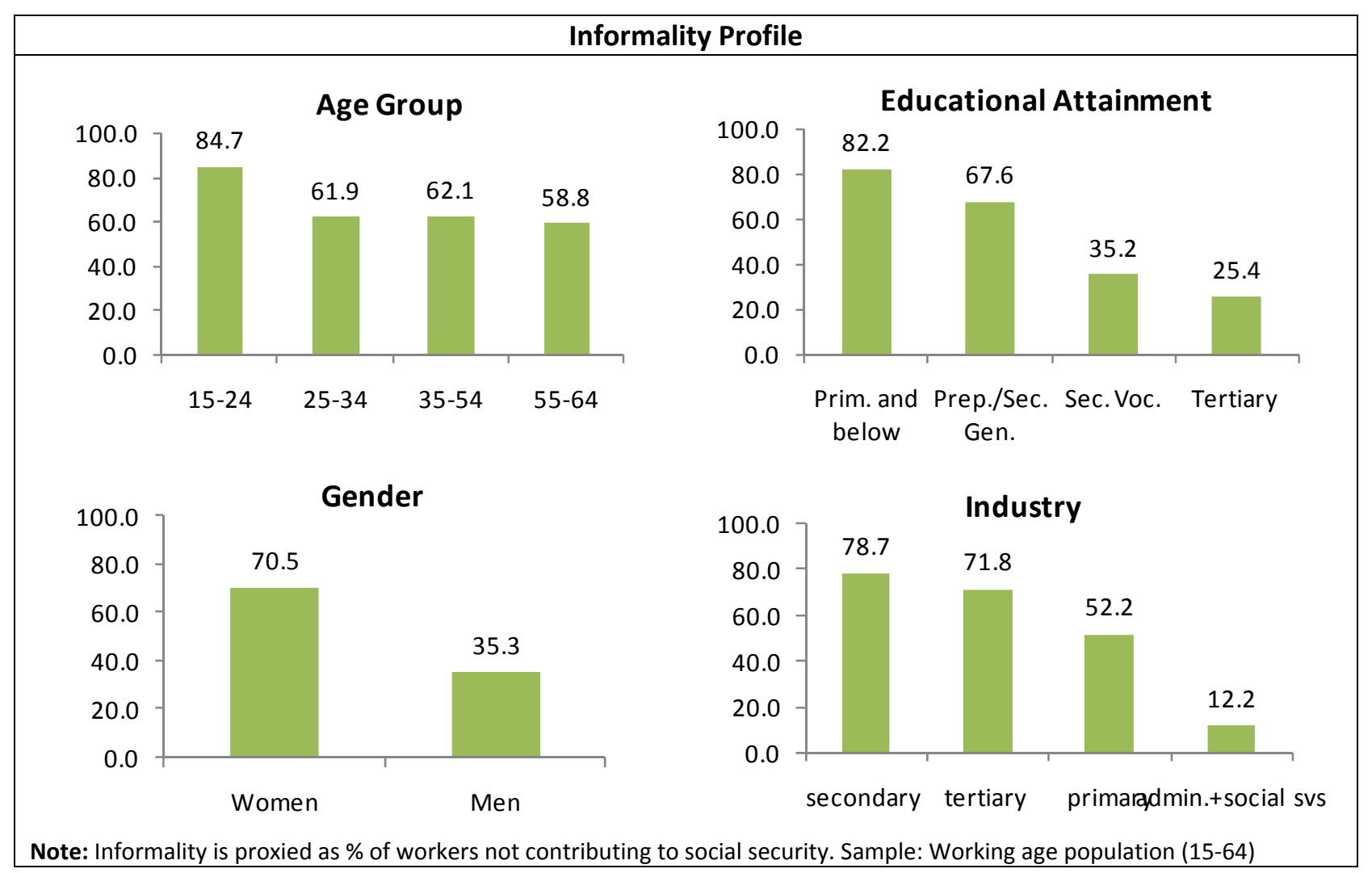




\section{Informality Determinants}

Marginal Increase in the Probability of being "informal" according to the characteristics of the worker.

\begin{tabular}{|c|c|c|c|}
\hline & \multicolumn{3}{|c|}{ All } \\
\hline & Total & Male & Female \\
\hline Urban dummy & N.S. & N.S. & N.S. \\
\hline Male dummy & 10.4 & & \\
\hline Married & N.S. & N.S. & N.S. \\
\hline \multicolumn{4}{|l|}{ Age Group (youth 15-24) } \\
\hline $25-34$ & -6.4 & -7.3 & N.S. \\
\hline $35-54$ & -10.9 & -12.4 & N.S. \\
\hline $55-64$ & -23.4 & -26.4 & N.S. \\
\hline \multicolumn{4}{|l|}{ Education (omitted: primary and below) } \\
\hline Preparatory/Sec. Gen. & -5.3 & -4.4 & -3.7 \\
\hline Sec. Vocational & -14.2 & -13.9 & -5.9 \\
\hline Tertiary & -11.9 & -11.9 & -4.4 \\
\hline \multicolumn{4}{|c|}{ Occupation (omitted: elementary occupations) } \\
\hline Legislators/Officials/managers & -17.8 & $\underline{-16.5}$ & N.S. \\
\hline Professionals & -30.9 & $\overline{-33.0}$ & N.S. \\
\hline Technicians & -23.9 & -26.5 & N.S. \\
\hline Clerks & -23.0 & -24.0 & N.S. \\
\hline Service workers/salesmen & N.S. & N.S. & N.S. \\
\hline Skilled agricultural/fishery worker & N.S. & N.S. & N.S. \\
\hline Craft and related trade workers & 11.3 & 11.7 & N.S. \\
\hline Operators & -15.3 & -15.5 & -3.4 \\
\hline \multicolumn{4}{|l|}{ Activity (omitted: primary sector) } \\
\hline Secondary sector & N.S. & N.S. & N.S. \\
\hline Tertiary sector & 10.1 & 15.0 & N.S. \\
\hline Public adm.\&social service & N.S. & N.S. & N.S. \\
\hline \multicolumn{4}{|l|}{ Ownership if the firm (vs. private firms) } \\
\hline Public firms & -80.0 & -78.3 & -67.2 \\
\hline Observations & 11999 & 10343 & 1653 \\
\hline
\end{tabular}

Note: Informality is proxied as \% of workers not contributing to social security. Coefficients reported in the table are multiplied by 100 . Underlined coefficients are significant at a 10 percent confidence level. N.S. is not significant. Other coefficients are significant at a 5 percent confidence level. 


\begin{tabular}{|l|l|}
\hline Lebanon & $\begin{array}{l}\text { Data Source: Lebanon National Survey of } \\
\text { Household Living Conditions (LSMS) } 2004\end{array}$ \\
\hline
\end{tabular}

\begin{tabular}{|r|c|c|c|}
\hline \multicolumn{2}{|c|}{ Informality Levels } & Rrban \\
\hline
\end{tabular}

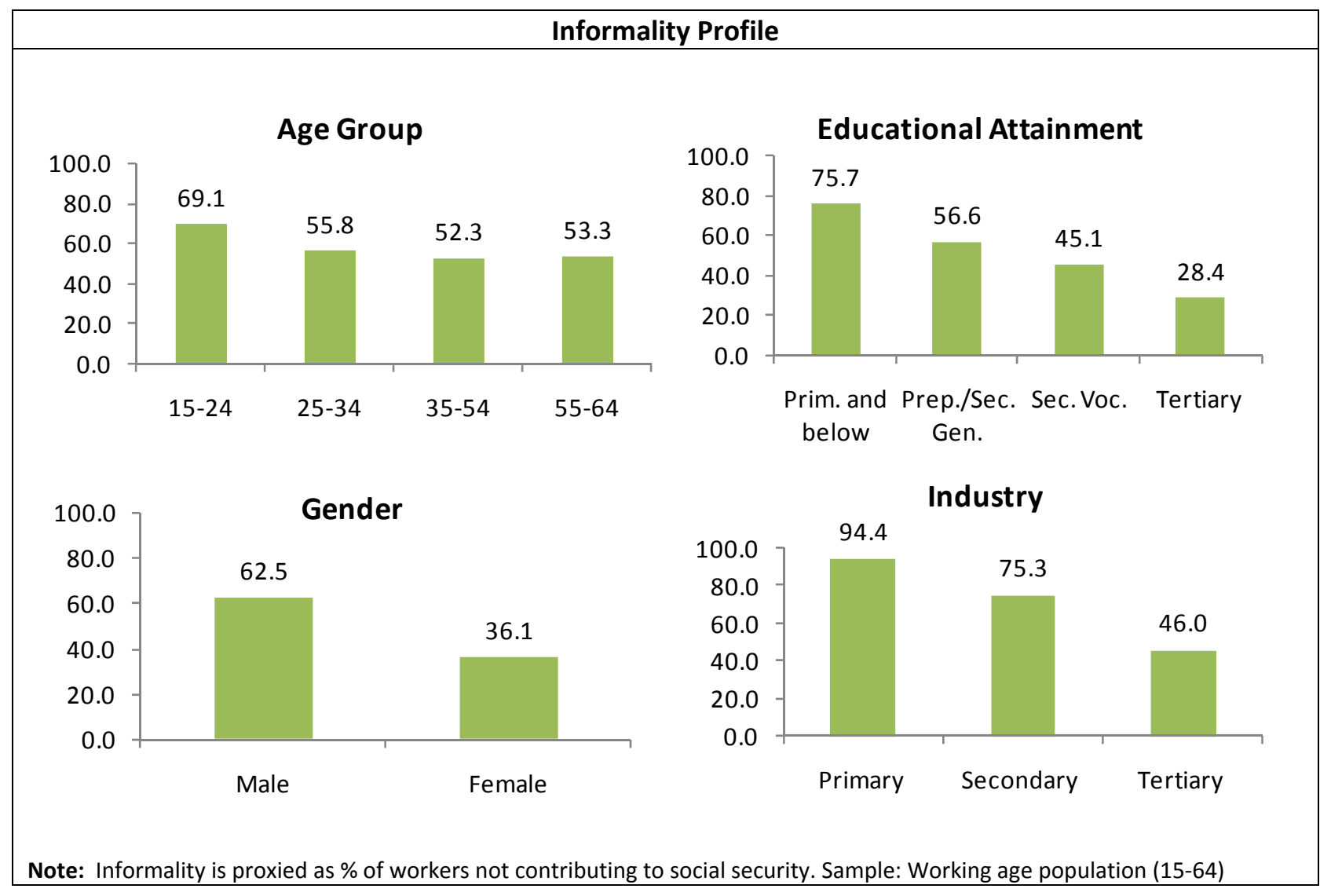




\begin{tabular}{|c|c|c|c|}
\hline \multicolumn{4}{|c|}{ Informality Determinants } \\
\hline \multicolumn{4}{|c|}{ Marginal Increase in the Probability of being "informal" according to the characteristics of the worker. } \\
\hline & \multicolumn{3}{|c|}{ All } \\
\hline & Total & Male & Female \\
\hline Urban dummy & -11.4 & -11.8 & -7.9 \\
\hline Male dummy & 7.4 & & \\
\hline Married & -14.8 & -12.4 & -20.8 \\
\hline \multicolumn{4}{|l|}{ Age Group (youth 15-24) } \\
\hline $25-34$ & -6.1 & -6.7 & -7.3 \\
\hline $35-54$ & -15.9 & -17.4 & -16.4 \\
\hline $55-64$ & -24.0 & -25.8 & -21.0 \\
\hline \multicolumn{4}{|l|}{ Education (omitted: primary and below) } \\
\hline Preparatory/Sec. Gen. & -14.1 & -11.5 & -26.1 \\
\hline Sec. Vocational & -24.8 & -21.0 & -32.5 \\
\hline Tertiary & -32.8 & -30.6 & -40.9 \\
\hline \multicolumn{4}{|c|}{ Occupation (omitted: elementary occupations) } \\
\hline Legislators/Officials/managers & $\mathrm{n} / \mathrm{a}$ & $\mathrm{n} / \mathrm{a}$ & $\mathrm{n} / \mathrm{a}$ \\
\hline Professionals & $\mathrm{n} / \mathrm{a}$ & $\mathrm{n} / \mathrm{a}$ & $\mathrm{n} / \mathrm{a}$ \\
\hline Technicians & $\mathrm{n} / \mathrm{a}$ & $\mathrm{n} / \mathrm{a}$ & $\mathrm{n} / \mathrm{a}$ \\
\hline Clerks & $\mathrm{n} / \mathrm{a}$ & $\mathrm{n} / \mathrm{a}$ & $\mathrm{n} / \mathrm{a}$ \\
\hline Service workers/salesmen & $\mathrm{n} / \mathrm{a}$ & $\mathrm{n} / \mathrm{a}$ & $\mathrm{n} / \mathrm{a}$ \\
\hline Skilled agricultural/fishery worker & $\mathrm{n} / \mathrm{a}$ & $\mathrm{n} / \mathrm{a}$ & $\mathrm{n} / \mathrm{a}$ \\
\hline Craft and related trade workers & $\mathrm{n} / \mathrm{a}$ & $\mathrm{n} / \mathrm{a}$ & $\mathrm{n} / \mathrm{a}$ \\
\hline Operators & $\mathrm{n} / \mathrm{a}$ & $\mathrm{n} / \mathrm{a}$ & $\mathrm{n} / \mathrm{a}$ \\
\hline \multicolumn{4}{|l|}{ Activity (omitted: primary sector) } \\
\hline Secondary sector & -19.5 & -19.0 & -12.9 \\
\hline Tertiary sector & -32.7 & -32.3 & -19.5 \\
\hline Public adm.\&social service & $\mathrm{n} / \mathrm{a}$ & $\mathrm{n} / \mathrm{a}$ & $\mathrm{n} / \mathrm{a}$ \\
\hline \multicolumn{4}{|l|}{ Ownership if the firm (vs. private firms) } \\
\hline Public firms & -45.3 & -52.2 & -21.1 \\
\hline Observations & 14533 & 11586 & 2947 \\
\hline \multicolumn{4}{|c|}{$\begin{array}{l}\text { Note: Informality is proxied as } \% \text { of workers not contributing to social security. Coefficients } \\
\text { reported in the table are multiplied by } 100 \text {. Underlined coefficients are significant at a } 10 \text { percent } \\
\text { confidence level. N.S. is not significant. Other coefficients are significant at a } 5 \text { percent confidence } \\
\text { level. }\end{array}$} \\
\hline
\end{tabular}




\begin{tabular}{|l|l|}
\hline Morocco & \begin{tabular}{l} 
- $\begin{array}{l}\text { Data Source: Morocco Household } \\
\text { Consumption and Expenditure Survey } \\
2001\end{array}$ \\
\hline
\end{tabular} \\
\hline
\end{tabular}

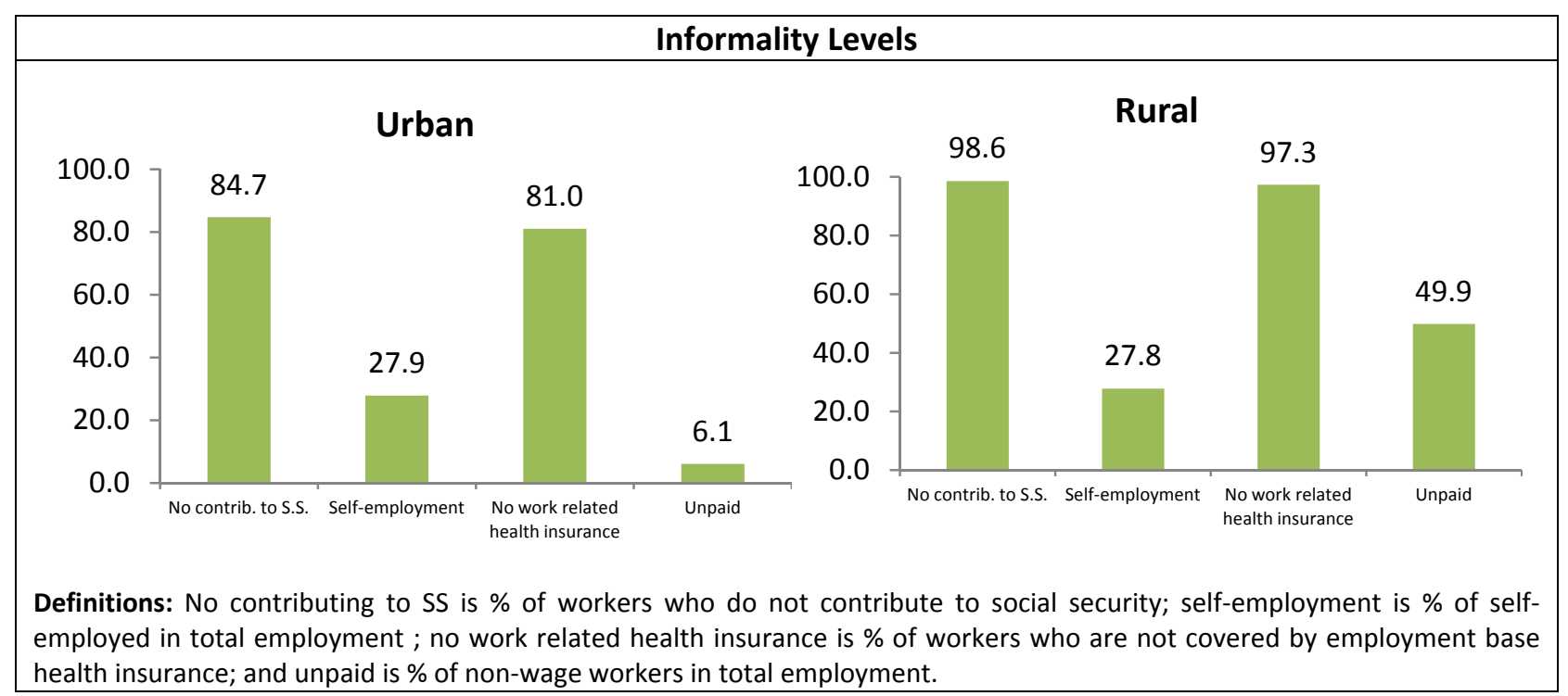

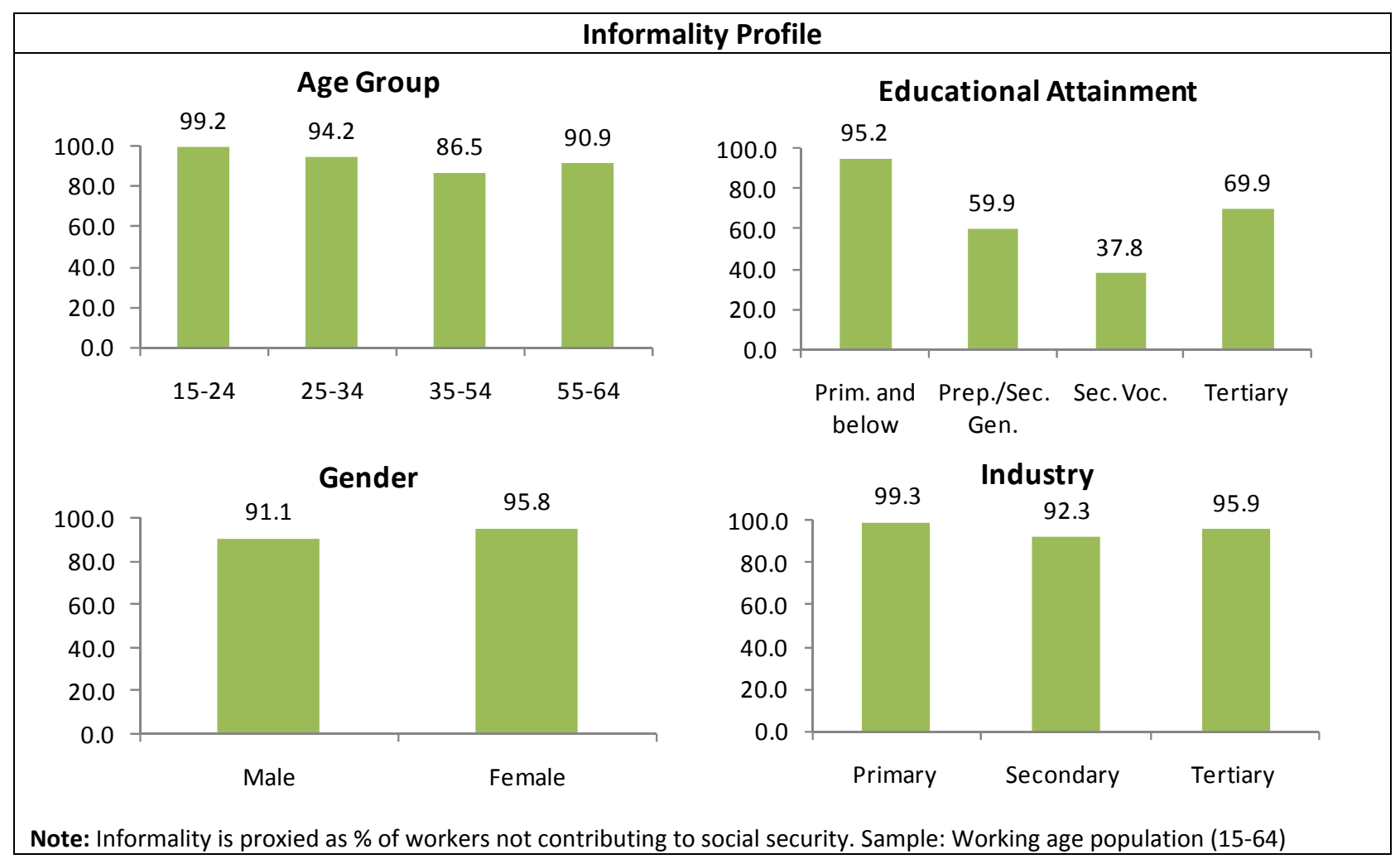




\section{Informality Determinants}

Marginal Increase in the Probability of being "informal" according to the characteristics of the worker.

\begin{tabular}{|c|c|c|c|}
\hline & \multicolumn{3}{|c|}{ All } \\
\hline & Total & Male & Female \\
\hline Urban dummy & -1.3 & -2.3 & -0.2 \\
\hline Male dummy & -0.4 & & \\
\hline Married & -1.1 & -2.5 & -0.2 \\
\hline \multicolumn{4}{|l|}{ Age Group (youth 15-24) } \\
\hline $25-34$ & -1.2 & -2.4 & -0.2 \\
\hline $35-54$ & -2.7 & -5.2 & -0.5 \\
\hline $55-64$ & -5.0 & -8.6 & -1.5 \\
\hline \multicolumn{4}{|l|}{ Education (omitted: primary and below) } \\
\hline Preparatory/Sec. Gen. & -0.9 & -1.9 & -0.2 \\
\hline Sec. Vocational & -2.9 & -4.8 & -0.9 \\
\hline Tertiary & -2.7 & -7.5 & -0.3 \\
\hline \multicolumn{4}{|c|}{ Occupation (omitted: elementary occupations) } \\
\hline Legislators/Officials/managers & -9.1 & -12.9 & -3.4 \\
\hline Professionals & -4.5 & -7.4 & -1.0 \\
\hline \multicolumn{4}{|l|}{ Technicians } \\
\hline Clerks & -6.2 & -11.7 & -0.7 \\
\hline Service workers/salesmen & N.S. & N.S. & N.S. \\
\hline Skilled agricultural/fishery worker & 0.4 & N.S. & N.S. \\
\hline Craft and related trade workers & 0.5 & 1.1 & N.S. \\
\hline Operators & -1.2 & -2.1 & N.S. \\
\hline \multicolumn{4}{|l|}{ Activity (omitted: primary sector) } \\
\hline Secondary sector & -0.7 & -1.0 & -0.7 \\
\hline Tertiary sector & 0.4 & $\underline{0.8}$ & N.S. \\
\hline Public adm.\&social service & $\overline{-2.7}$ & $\overline{-4.8}$ & -1.4 \\
\hline \multicolumn{4}{|l|}{ Ownership if the firm (vs. private firms) } \\
\hline Public firms & & & \\
\hline Observations & 24278 & 15417 & 8861 \\
\hline
\end{tabular}

Note: Informality is proxied as \% of workers not contributing to social security. Coefficients reported in the table are multiplied by 100 . Underlined coefficients are significant at a 10 percent confidence level. N.S. is not significant. Other coefficients are significant at a 5 percent confidence level. 


\begin{tabular}{|c|c|}
\hline Syria & $\begin{array}{l}\text { - Data Source: Syria Income and } \\
\text { Expenditure Survey } 2004\end{array}$ \\
\hline
\end{tabular}

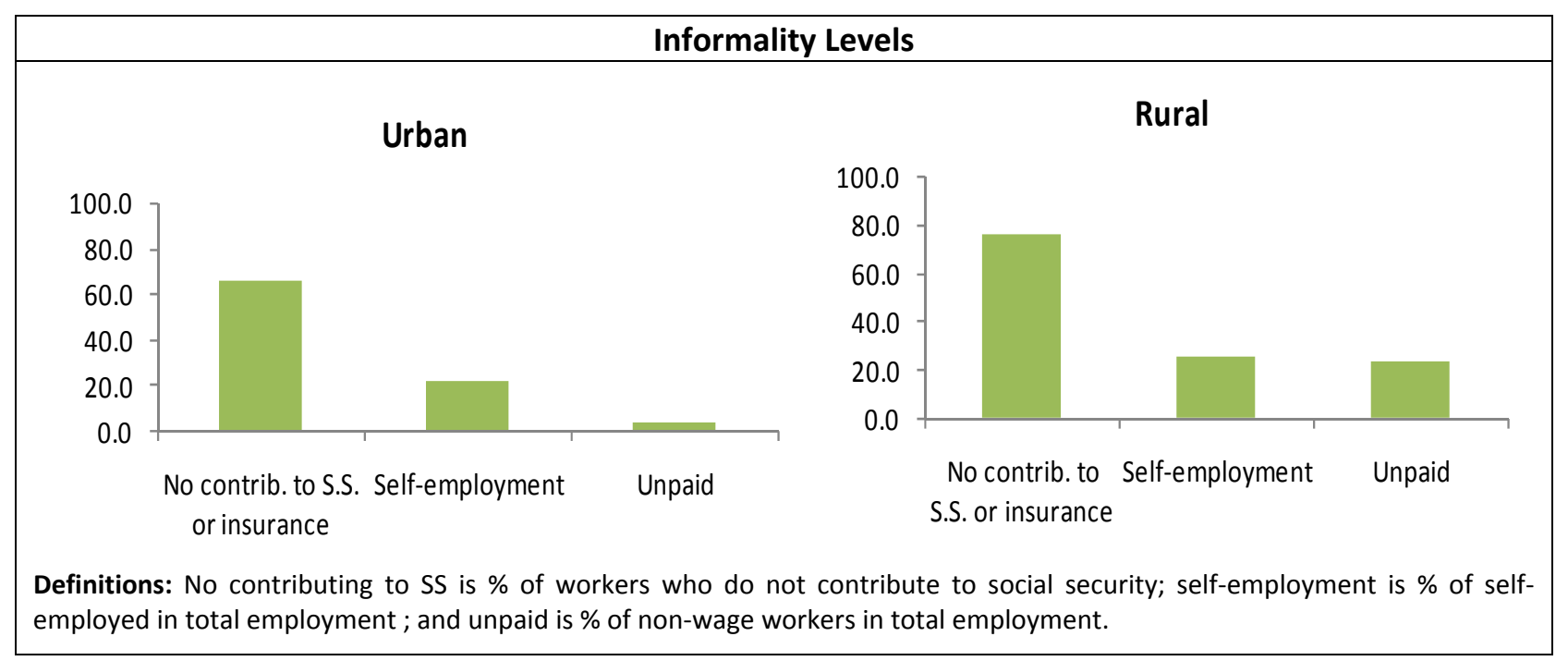

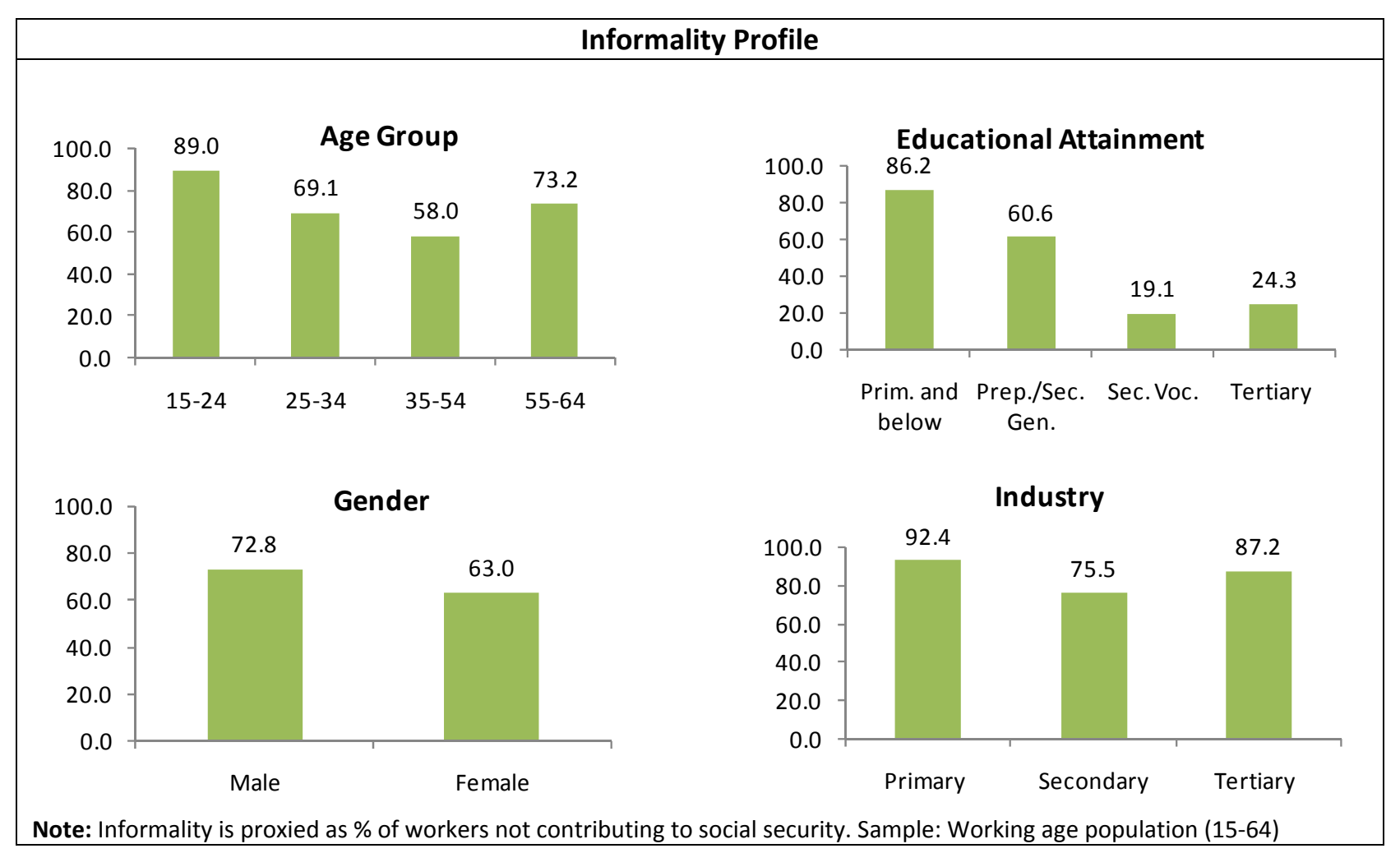




\section{Informality Determinants}

Marginal Increase in the Probability of being "informal" according to the characteristics of the worker.

\begin{tabular}{|c|c|c|c|}
\hline & \multicolumn{3}{|c|}{ All } \\
\hline & Total & Male & Female \\
\hline Urban dummy & 2.9 & 3.9 & -3.4 \\
\hline Male dummy & 2.3 & & \\
\hline Married & -5.0 & -6.2 & N.S. \\
\hline \multicolumn{4}{|l|}{ Age Group (youth 15-24) } \\
\hline $25-34$ & -17.8 & -18.2 & -9.8 \\
\hline $35-54$ & -22.8 & -22.9 & -15.4 \\
\hline $55-64$ & -29.6 & -28.7 & -29.2 \\
\hline \multicolumn{4}{|l|}{ Education (omitted: primary and below) } \\
\hline Preparatory/Sec. Gen. & -08.7 & -8.4 & -6.4 \\
\hline Sec. Vocational & -18.4 & -15.6 & -21.9 \\
\hline Tertiary & 6.1 & -6.2 & -30.2 \\
\hline \multicolumn{4}{|c|}{ Occupation (omitted: elementary occupations) } \\
\hline Legislators/Officials/managers & -43.0 & -51.9 & N.S. \\
\hline Professionals & -28.0 & -30.8 & N.S. \\
\hline Technicians & -22.4 & -18.0 & -29.8 \\
\hline Clerks & -4.3 & -5.4 & $\underline{11.3}$ \\
\hline Service workers/salesmen & -18.1 & -17.1 & $\overline{\text { N.S. }}$ \\
\hline Skilled agricultural/fishery worker & 7.9 & 5.8 & 21.3 \\
\hline Craft and related trade workers & -22.4 & -23.8 & N.S. \\
\hline Operators & -18.2 & -17.8 & -21.8 \\
\hline \multicolumn{4}{|l|}{ Activity (omitted: primary sector) } \\
\hline Secondary sector & -11.7 & -12.5 & N.S. \\
\hline Tertiary sector & 1.4 & N.S. & N.S. \\
\hline Public adm.\&social service & $\mathrm{n} / \mathrm{a}$ & $\mathrm{n} / \mathrm{a}$ & $\mathrm{n} / \mathrm{a}$ \\
\hline \multicolumn{4}{|l|}{ Ownership if the firm (vs. private firms) } \\
\hline Public firms & -65.7 & -68.2 & -61.3 \\
\hline Observations & 47468 & 38818 & 8650 \\
\hline
\end{tabular}

Note: Informality is proxied as \% of workers not contributing to social security. Coefficients reported in the table are multiplied by 100 . Underlined coefficients are significant at a 10 percent confidence level. N.S. is not significant. Other coefficients are significant at a 5 percent confidence level. 


\begin{tabular}{|l|l|}
\hline Yemen & \begin{tabular}{l} 
- $\begin{array}{l}\text { Data Source: Yemen Household Budget } \\
\text { Survey } 2006\end{array}$ \\
\hline
\end{tabular} \\
\hline
\end{tabular}

\begin{tabular}{|l|l|l|}
\hline & Informality Levels \\
\hline
\end{tabular}

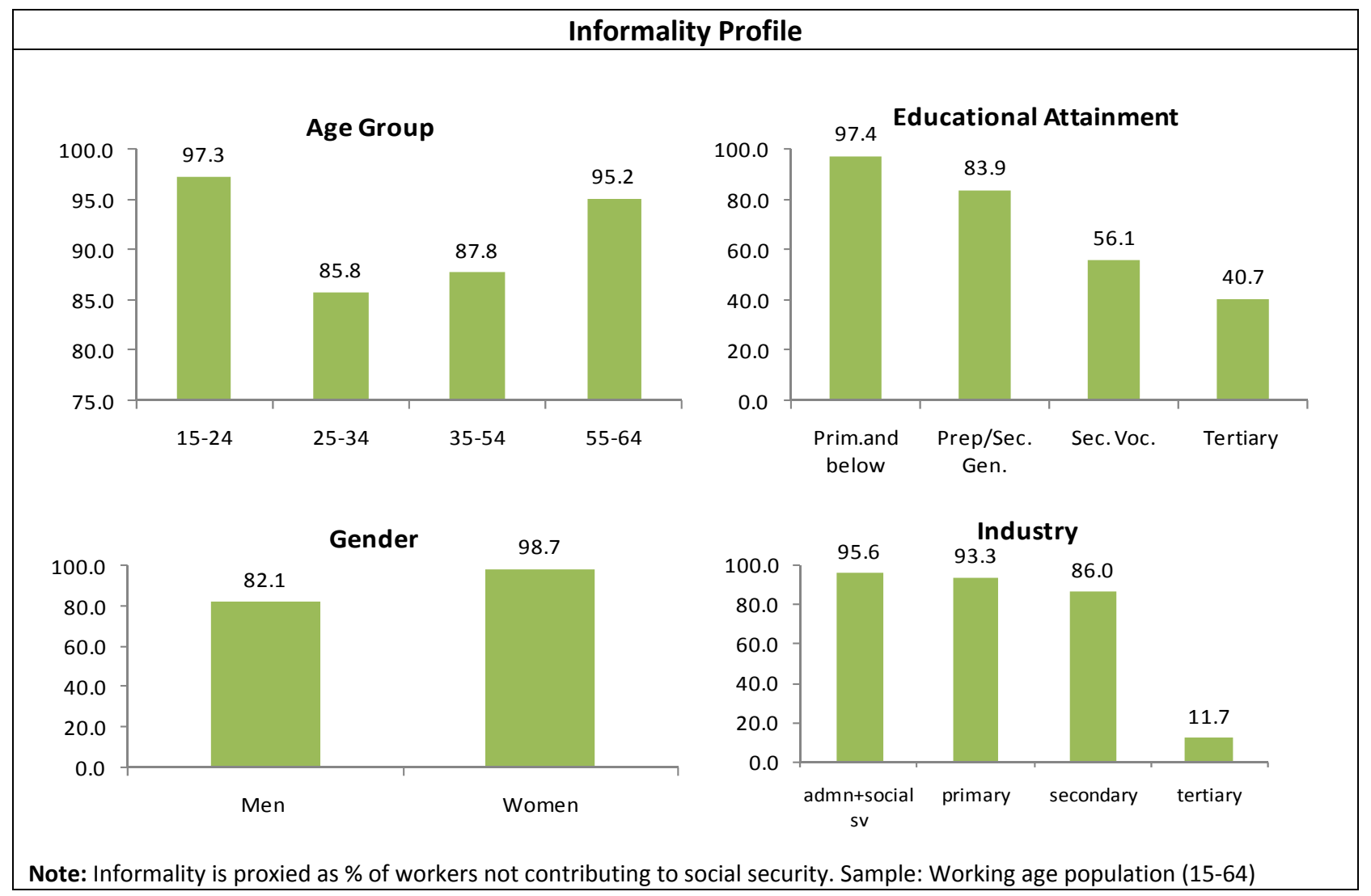




\section{Informality Determinants}

Marginal Increase in the Probability of being "informal" according to the characteristics of the worker.

\begin{tabular}{|c|c|c|c|}
\hline & \multicolumn{3}{|c|}{ All } \\
\hline & Total & Male & Female \\
\hline Urban dummy & -4.3 & -4.4 & N.S. \\
\hline Male dummy & N.S. & & \\
\hline Married & -4.3 & N.S. & -14.0 \\
\hline \multicolumn{4}{|l|}{ Age Group (youth 15-24) } \\
\hline $25-34$ & -15.8 & -15.7 & -14.3 \\
\hline $35-54$ & -25.6 & -24.2 & -26.3 \\
\hline $55-64$ & -24.6 & -22.7 & -25.1 \\
\hline \multicolumn{4}{|l|}{ Education (omitted: primary and below) } \\
\hline Preparatory/Sec. Gen. & -10.4 & -9.3 & N.S. \\
\hline Sec. Vocational & -24.8 & -20.6 & -24.7 \\
\hline Tertiary & -10.6 & -9.6 & N.S. \\
\hline \multicolumn{4}{|c|}{ Occupation (omitted: elementary occupations) } \\
\hline Legislators/Officials/managers & -35.9 & -33.5 & -27.5 \\
\hline Professionals & -24.6 & -24.7 & -27.6 \\
\hline Technicians & -25.1 & -25.0 & -27.2 \\
\hline Clerks & -17.8 & -14.3 & -23.1 \\
\hline Service workers/salesmen & -24.0 & -21.9 & -22.0 \\
\hline Skilled agricultural/fishery worker & 23.8 & 22.6 & N.S. \\
\hline Craft and related trade workers & N.S. & N.S. & N.S. \\
\hline Operators & -16.0 & -15.4 & N.S. \\
\hline \multicolumn{4}{|l|}{ Activity (omitted: primary sector) } \\
\hline Secondary sector & -14.0 & -14.8 & N.S. \\
\hline Tertiary sector & 15.5 & 14.2 & N.S. \\
\hline Public adm.\&social service & N.S. & N.S. & 21.7 \\
\hline \multicolumn{4}{|l|}{ Ownership if the firm (vs. private firms) } \\
\hline Public firms & -79.1 & -78.0 & -85.4 \\
\hline Observations & 9801 & 8902 & 899 \\
\hline
\end{tabular}

Note: Informality is proxied as \% of workers not contributing to social security. Coefficients reported in the table are multiplied by 100 . Underlined coefficients are significant at a 10 percent confidence level. N.S. is not significant. Other coefficients are significant at a 5 percent confidence level. 
Table A1: Description of the data used for the analysis

\begin{tabular}{lll}
\hline Country & Survey & Year \\
\hline Egypt & $\begin{array}{l}\text { Labor Market } \\
\text { Panel Surveys } \\
\text { (ELMPS) }\end{array}$ & \\
& \\
& \\
& \\
Iraq & $\begin{array}{l}\text { Household } \\
\text { Socio- } \\
\text { economic } \\
\text { Survey (IHSES) }\end{array}$ \\
& 2006/2007
\end{tabular}

Description

ELMPS was conducted by the Population Council and CAPMAS with support of USAID Egypt and Ford Foundation. The ELMPS 06 is designed as a panel survey in the sense that it follows the same households and individuals that were interviewed in the Egypt Labor Market Survey of 1998 and re-interviews them. Individuals who split from the original 1998 households in the intervening period are also tracked and interviewed together with their entire household. Of the 8,371 households interviewed in 2006, 3,701 were households that were interviewed in ELMS 1998, 2,167 were splits from the original households, and 2,498 were part of an entirely new refresher sample. Sample size is 17,364 individuals and 8,371 households. The surveys contain rich information about individuals' education, employment status, occupation, economic activity, firm size, wage, pension contribution, etc.

In an effort of reducing poverty and promoting social development, the Ministry of Planning and Development Corporation and the Central Organization for Statistics and Information Technology had undertaken IHSES with the support of the World Bank. Providing essential data for understanding the nature and causes of poverty among Iraqi households, IHSES is the largest household social and economic survey ever conducted in Iraq that reached a total of 18,144 households. IHSES provides information of education, labor, health, income and expenditure in Iraq. IHEES has a sample size of 17,822 households and 127,189 individuals.

\begin{tabular}{|c|c|c|c|}
\hline Jordan & $\begin{array}{l}\text { Labor Market } \\
\text { Survey }\end{array}$ & 2010 & $\begin{array}{l}\text { The Jordan Labor Market Panel survey (JLMPS 2010) was carried out } \\
\text { by Economic Research Forum in cooperation with the National Center } \\
\text { for Human Resource Development (NCHRD) and the Jordanian } \\
\text { Department of Statistics (DOS). For the first time in Jordan, detailed } \\
\text { information about labor market experiences and behaviors is } \\
\text { available in JLMPS. JLMPS has a sample size of } 25,969 \text { individuals } \\
\text { containing rich information about individuals' education, employment } \\
\text { status, occupation, economic activity, firm size, wage, pension } \\
\text { contribution, and decision making of labor force participation. JLMPS } \\
\text { allows for a much richer linking of individual characteristics with labor } \\
\text { market outcomes. }\end{array}$ \\
\hline Lebanon & $\begin{array}{l}\text { National Survey } \\
\text { of Household } \\
\text { Living } \\
\text { Conditions } \\
\text { (NHS) }\end{array}$ & 2004 & $\begin{array}{l}\text { The National Survey of Household Living Conditions is the } \\
\text { multipurpose survey conducted by the Ministry of Social Affairs, the } \\
\text { Central Administration for Statistics and the UNDP in 2004. The } \\
\text { purpose of this survey is to assess the economic and social conditions } \\
\text { of the households in Lebanon prior to the attacks. It provides varied } \\
\text { data and social indicators on Lebanese households': demographic } \\
\text { status, educational conditions, employment and unemployment, } \\
\text { health insurance, chronic diseases, disability, and leisure activities. } \\
\text { The survey also provides data concerning the characteristics of } \\
\text { residences and their available appliances. Out of the sample size } \\
14,948,13,003 \text { households - consisting of } 56,513 \text { individuals - } \\
\text { completed the data in the questionnaire. The response rate reached } \\
87 \% \text { of the households sampled. }\end{array}$ \\
\hline
\end{tabular}




\begin{tabular}{|c|c|c|c|}
\hline Morocco & $\begin{array}{l}\text { Household } \\
\text { Consumption } \\
\text { and } \\
\text { Expenditure } \\
\text { Survey (HCES) }\end{array}$ & 2001 & $\begin{array}{l}\text { HCES was conducted in } 2000 / 2001 \text { by Ministry of Economic Forecasts } \\
\text { and Planning. The purpose of this survey was to provide information } \\
\text { concerning the living condition of households and the structure of } \\
\text { their consumption and expenditure. HCES provides demographic } \\
\text { characteristics of the family members, education, employment, } \\
\text { household consumption and expenditures, and income. HCES has } \\
14,243 \text { household and } 85,509 \text { individual observations. }\end{array}$ \\
\hline Syria & $\begin{array}{l}\text { Household } \\
\text { Income and } \\
\text { Expenditure } \\
\text { Survey (HIES) }\end{array}$ & 2004 & $\begin{array}{l}\text { Syria Household Income and Expenditure Surveys (HIES) 2003-2004 } \\
\text { was conducted by the Central Bureau for Statistics (CBS), Syria's } \\
\text { official statistical agency. HIES provides information on education, } \\
\text { employment, household expenditure and housing condition. HIEA } \\
\text { has a sample size of } 29,790 \text { households and } 173,330 \text { individuals. }\end{array}$ \\
\hline Yemen & $\begin{array}{l}\text { Household } \\
\text { Budget Survey } \\
\text { (HBS) }\end{array}$ & $2005 / 2006$ & $\begin{array}{l}\text { The Household Budget Survey } 2005-06 \text { was conducted by the Central } \\
\text { Statistical Organization of Yemen. The HBS data contain information } \\
\text { on household roster, economic activities, dwelling conditions, health, } \\
\text { education, anthropometrics, income, durable goods and } \\
\text { consumption. One of the main objectives of the HBS } 2005 / 2006 \text { is } \\
\text { producing aggregates of the statistical indicators at the level of the } \\
\text { urban and rural communities of each governorate in order to serve } \\
\text { the purposes of economic and social development-planning on the } \\
\text { central and local levels. HBS } 2005 \text { consists with } 13,136 \text { household and } \\
98,941 \text { individual observations. }\end{array}$ \\
\hline
\end{tabular}

Source: Author's own elaboration. 
Table A2: Informality Profile [All Workers]

\begin{tabular}{|c|c|c|c|c|c|c|c|c|c|c|c|c|c|c|}
\hline & \multicolumn{2}{|c|}{ Iraq } & \multicolumn{2}{|c|}{ Egypt } & \multicolumn{2}{|c|}{ Lebanon } & \multicolumn{2}{|c|}{ Morocco } & \multicolumn{2}{|c|}{ Syria } & \multicolumn{2}{|c|}{ Yemen } & \multicolumn{2}{|c|}{ Jordan } \\
\hline ALL WORKERS & \% Pop. & \%Inf. & \% Pop. & \%Inf. & \% Pop. & $\%$ Inf. & \% Pop. & \%Inf. & \% Pop. & \%Inf. & \% Pop. & \%Inf. & \% Pop. & \%Inf. \\
\hline National level & 100.0 & 66.9 & 100.0 & 58.3 & 100.0 & 56.2 & 100.0 & 81.9 & 100.0 & 71.0 & 100.0 & 91.4 & 100.0 & 44.2 \\
\hline Urban & 72.9 & 63.5 & 43.0 & 42.7 & 50.1 & 48.3 & 56.5 & 72.7 & 50.4 & 65.9 & 28.2 & 84.7 & 82.9 & 47.5 \\
\hline Rural & 27.1 & 76.1 & 57.0 & 70.0 & 49.9 & 66.7 & 43.5 & 93.8 & 49.6 & 76.3 & 71.8 & 94.0 & 17.1 & 28.3 \\
\hline \multicolumn{15}{|l|}{ Gender } \\
\hline Male & 89.8 & 70.5 & 76.9 & 57.9 & 76.2 & 62.5 & 84.0 & 83.5 & 81.8 & 72.8 & 44.0 & 82.1 & 83.0 & 47.8 \\
\hline Female & 10.2 & 35.3 & 23.1 & 59.3 & 23.9 & 36.1 & 16.0 & 73.2 & 18.2 & 63.0 & 56.0 & 98.7 & 17.0 & 26.7 \\
\hline \multicolumn{15}{|l|}{ Marital Status } \\
\hline Single & 30.8 & 73.7 & 29.4 & 76.4 & 41.4 & 62.3 & 40.3 & 86.4 & 64.4 & 95.4 & 64.4 & 95.4 & 35.7 & 43.3 \\
\hline Married & 69.2 & 63.85 & 70.7 & 50.7 & 58.6 & 53.4 & 59.7 & 78.8 & 57.9 & 63.3 & 35.6 & 89.2 & 64.4 & 44.7 \\
\hline \multicolumn{15}{|l|}{ Age group } \\
\hline $15-24$ & 22.3 & 84.7 & 19.5 & 87.1 & 16.4 & 69.1 & 17.1 & 90.9 & 29.2 & 89.0 & 38.0 & 97.3 & 18.5 & 49.9 \\
\hline $25-34$ & 35.6 & 61.9 & 31.5 & 61.4 & 30.8 & 55.8 & 28.7 & 85.2 & 26.5 & 69.1 & 25.5 & 85.8 & 35.8 & 36.9 \\
\hline $35-54$ & 36.5 & 62.1 & 40.6 & 43.4 & 43.3 & 52.3 & 43.1 & 76.8 & 37.5 & 58.0 & 30.2 & 87.8 & 40.7 & 45.6 \\
\hline $55-64$ & 5.64 & 58.8 & 8.4 & 51.2 & 9.5 & 53.3 & 11.1 & 79.2 & 6.9 & 73.2 & 6.2 & 95.2 & 5.0 & 63.9 \\
\hline \multicolumn{15}{|l|}{ Education } \\
\hline Primary or bellow & 45.9 & 82.2 & 42.4 & 77.8 & 38.8 & 75.7 & 64.2 & 90.9 & 64.6 & 86.2 & 80.2 & 97.4 & 10.8 & 71.9 \\
\hline Preparatory/Sec. General & 24.1 & 67.6 & 6.4 & 63.7 & 36.7 & 56.6 & 27.8 & 74.1 & 19.6 & 60.6 & 13.7 & 83.9 & 46.7 & 48.1 \\
\hline Secondary Vocational & 17.2 & 35.2 & 34.4 & 50.0 & 7.4 & 45.1 & N/A & $N / A$ & 8.4 & 19.1 & 0.7 & 56.1 & 16.7 & 34.2 \\
\hline Tertiary Education & 12.8 & 25.4 & 16.8 & 23.7 & 17.2 & 28.4 & 8.0 & 36.5 & 7.4 & 24.3 & 5.4 & 40.7 & 25.8 & 22.0 \\
\hline \multicolumn{15}{|l|}{ Employment Status } \\
\hline Wage worker & 68.9 & 51.7 & 64.3 & 42.6 & 65.4 & 43.1 & 51.4 & 67.1 & 55.6 & 52.2 & 23.9 & 63.7 & 81.7 & 32.4 \\
\hline Employer & $n / a$ & $\mathrm{n} / \mathrm{a}$ & 13.2 & 78.4 & 4.8 & 84.0 & 3.9 & 98.4 & 6.7 & 89.4 & $\mathrm{n} / \mathrm{a}$ & $\mathrm{n} / \mathrm{a}$ & 7.2 & 94.6 \\
\hline self-employed & 20.5 & 100.0 & 9.9 & 82.1 & 27.2 & 80.1 & 29.6 & 98.1 & 24.0 & 93.4 & 20.3 & 100.0 & 9.9 & 98.5 \\
\hline Unpaid worker & 10.6 & 100.0 & 12.6 & 98.3 & 2.6 & 86.0 & 15.2 & 99.0 & 13.8 & 99.2 & 55.9 & 100.0 & 1.1 & 100.0 \\
\hline \multicolumn{15}{|l|}{ Industry * } \\
\hline Primary sector & 4.6 & 52.2 & 25.5 & 94.1 & 6.6 & 94.4 & 28.4 & 94.1 & 31.6 & 92.4 & 18.4 & 95.6 & 4.4 & 82.3 \\
\hline Secondary sector & 30.7 & 78.7 & 21.3 & 65.8 & 24.5 & 75.3 & 12.6 & 78.9 & 6.1 & 75.5 & 3.4 & 86.0 & 20.6 & 61.8 \\
\hline Tertiary sector & 27.5 & 71.8 & 28.0 & 62.7 & 68.9 & 46.0 & 54.5 & 82.2 & 37.7 & 87.2 & 40.0 & 93.3 & 31.9 & 71.3 \\
\hline Public admin. an social svs & 37.2 & 12.2 & 25.3 & 11.0 & - & - & 4.5 & 18.5 & 24.6 & 17.6 & 38.2 & 11.7 & 43.0 & 6.17 \\
\hline \multicolumn{15}{|l|}{$\begin{array}{l}\text { Ownership (only for wage } \\
\text { workers) }\end{array}$} \\
\hline Public Enterprises & 36.9 & 11.8 & 30.0 & 5.3 & 13.5 & 9.5 & 19.2 & 24.4 & 26.8 & 10.8 & 38.6 & 7.8 & 35.6 & 1.1 \\
\hline Private Enterprises & 63.1 & 99.1 & 70.0 & 81.0 & 86.5 & 63.6 & 80.8 & 77.3 & 73.2 & 93.1 & 61.4 & 97.9 & 64.4 & 68.0 \\
\hline
\end{tabular}

Source: Author's own elaboration. 
Table A3: Informality Profile [Private Sector Workers]

\begin{tabular}{|c|c|c|c|c|c|c|c|c|c|c|c|c|c|c|}
\hline & \multicolumn{2}{|c|}{ Iraq } & \multicolumn{2}{|c|}{ Egypt } & \multicolumn{2}{|c|}{ Lebanon } & \multicolumn{2}{|c|}{ Morocco } & \multicolumn{2}{|c|}{ Syria } & \multicolumn{2}{|c|}{ Yemen } & \multicolumn{2}{|c|}{ Jordan } \\
\hline PRIVATE SECTOR & \% Pop. & \%Inf. & \% Pop. & \%Inf. & \% Pop. & \%Inf. & \% Pop. & \%Inf. & \% Pop. & \%Inf. & \% Pop. & \%Inf. & \% Pop. & \%Inf. \\
\hline National level & 100.0 & 99.1 & 100.0 & 81.0 & 100.0 & 63.5 & 100.0 & 88.7 & 100.0 & 93.1 & 100.0 & 99.7 & 100.0 & 68.0 \\
\hline Urban & 68.7 & 99.0 & 37.4 & 67.3 & 58.1 & 53.8 & 53.5 & 83.0 & 47.7 & 90.4 & 26.0 & 99.0 & 89.7 & 67.7 \\
\hline Rural & 31.3 & 99.4 & 62.6 & 89.2 & 41.9 & 76.9 & 46.5 & 95.2 & 52.3 & 95.6 & 74.0 & 99.9 & 10.4 & 70.8 \\
\hline \multicolumn{15}{|l|}{ Gender } \\
\hline Men & 94.6 & 99.2 & 79.7 & 78.2 & 76.4 & 70.7 & 84.5 & 89.8 & 84.0 & 92.7 & 39.4 & 99.2 & 85.1 & 71.9 \\
\hline Women & 5.4 & 98.9 & 20.3 & 91.9 & 23.6 & 40.1 & 15.5 & 82.5 & 16.0 & 95.1 & 60.7 & 100.0 & 14.9 & 45.7 \\
\hline \multicolumn{15}{|l|}{ Marital Status } \\
\hline Single & 34.1 & 99.3 & 35.2 & 88.2 & 43.0 & 67.6 & 42.0 & 90.2 & 37.1 & 99.8 & 37.1 & 99.8 & 37.1 & 63.6 \\
\hline Married & 65.9 & 99.1 & 64.8 & 77.1 & 57.0 & 62.2 & 58.0 & 87.6 & 53.9 & 91.1 & 62.9 & 99.6 & 62.9 & 70.6 \\
\hline \multicolumn{15}{|l|}{ Age group } \\
\hline $15-24$ & 28.3 & 99.5 & 25.7 & 92.4 & 17.8 & 72.6 & 18.4 & 92.2 & 33.9 & 96.9 & 40.5 & 99.9 & 20.3 & 69.6 \\
\hline $25-34$ & 32.7 & 98.9 & 33.6 & 78.9 & 31.2 & 61.9 & 29.8 & 89.3 & 26.5 & 92.1 & 23.9 & 99.6 & 32.3 & 62.8 \\
\hline $35-54$ & 33.9 & 99.2 & 33.0 & 74.9 & 42.2 & 60.6 & 41.1 & 87.1 & 32.3 & 90.1 & 29.1 & 99.4 & 41.0 & 69.8 \\
\hline $55-64$ & 5.1 & 98.5 & 7.8 & 78.0 & 8.9 & 64.7 & 10.7 & 87.4 & 7.4 & 91.9 & 6.5 & 99.9 & 6.4 & 77.5 \\
\hline \multicolumn{15}{|l|}{ Education } \\
\hline Primary or bellow & 60.0 & 99.4 & 52.9 & 88.3 & 41.8 & 80.4 & 67.7 & 93.5 & 77.3 & 95.5 & 84.9 & 99.9 & 14.1 & 88.2 \\
\hline Preparatory/Sec. General & 25.8 & 99.1 & 7.2 & 80.1 & 36.0 & 66.0 & 26.4 & 84.8 & 17.0 & 89.8 & 12.4 & 99.3 & 48.0 & 74.3 \\
\hline Secondary Vocational & 9.2 & 98.4 & 30.4 & 77.8 & 7.3 & 51.5 & $N / A$ & N/A & 2.3 & 82.8 & 0.4 & 97.1 & 16.3 & 55.6 \\
\hline Tertiary Education & 4.9 & 97.5 & 9.5 & 50.5 & 14.9 & 34.3 & 5.9 & 50.7 & 3.5 & 61.9 & 2.3 & 94.9 & 21.5 & 40.2 \\
\hline \multicolumn{15}{|l|}{ Employment Status } \\
\hline Wage worker & 50.6 & 98.3 & 49.0 & 75.3 & 60.2 & 51.8 & 46.0 & 77.3 & 39.6 & 90.6 & 16.3 & 97.9 & 71.7 & 56.5 \\
\hline Employer & $n / a$ & $\mathrm{n} / \mathrm{a}$ & 18.8 & 78.4 & 5.6 & 84.1 & 4.3 & 98.4 & 9.2 & 89.6 & $\mathrm{n} / \mathrm{a}$ & $\mathrm{n} / \mathrm{a}$ & 11.2 & 94.6 \\
\hline self-employed & 32.6 & 100.0 & 14.1 & 82.1 & 31.3 & 80.2 & 32.8 & 98.1 & 32.6 & 93.5 & 22.3 & 100.0 & 15.4 & 98.5 \\
\hline Unpaid worker & 16.8 & 100.0 & 18.1 & 98.3 & 3.0 & 85.7 & 16.9 & 99.0 & 18.7 & 99.3 & 61.4 & 100.0 & 1.7 & 100.0 \\
\hline \multicolumn{15}{|l|}{ Industry * } \\
\hline Primary sector & 4.3 & 98.6 & 35.1 & 97.3 & 7.7 & 94.4 & 30.8 & 95.2 & 41.1 & 96.7 & 29.6 & 98.0 & 6.4 & 92.6 \\
\hline Secondary sector & 50.8 & 98.7 & 25.7 & 76.5 & 27.6 & 76.7 & 13.3 & 81.6 & 7.4 & 83.9 & 5.1 & 94.1 & 32.7 & 63.1 \\
\hline Tertiary sector & 41.2 & 98.6 & 35.3 & 70.4 & 64.7 & 54.5 & 55.3 & 87.4 & 47.5 & 93.9 & 61.6 & 98.7 & 49.0 & 75.1 \\
\hline Public admin. an social svs & 3.7 & 88.9 & 4.0 & 61.5 & - & - & 0.6 & 29.3 & 4.0 & 63.8 & 3.7 & 87.9 & 12.0 & 30.7 \\
\hline
\end{tabular}

Source: Author's own elaboration. 


\section{Social Protection Discussion Paper Series Titles}

No. $\quad \underline{\text { Title }}$

1201 Micro-Determinants of Informal Employment in The Middle East and North Africa Region

by Diego F. Angel-Urdinola and Kimie Tanabe, January 2012 (online only)

1119 Measuring Governance and Service Delivery in Safety Net Programs by Gloria M. Rubio, September 2011 (online only)

1118 Assessing Safety Net Readiness in Response to Food Price Volatility by Margaret Grosh, Colin Andrews, Rodrigo Quintana, Claudia Rodriguez-Alas, September 2011

1117 Social Safety Nets in Fragile States: A Community-Based School Feeding Program in Togo, August 2011 (also available in French)

1116 Strengthening Governance of Social Safety Nets in East Asia by Sara Giannozzi and Asmeen Khan, August 2011 (online only)

1115 International Portability of Health-Cost Coverage: Concepts and Experience by Martin Werding and Stuart McLennan, July 2011 (online only)

1114 Liberia’s Cash For Work Temporary Employment Project: Responding to Crisis in Low Income, Fragile Countries

by Colin Andrews, Prospère Backiny-Yetna, Emily Garin, Emily Weedon, Quentin Wodon and Giuseppe Zampaglione, July 2011

1113 Employability and Productivity among Older Workers: A Policy Framework and Evidence from Latin America

by Edmundo Murrugarra, July 2011 (online only)

1112 Cash Transfers, Children and the Crisis: Protecting Current and Future Investments by Ariel Fiszbein, Dena Ringold, Santhosh Srinivasan, June 2011 (online only)

1111 Severance Pay Programs around the World: History, Rationale, Status, and Reforms by Robert Holzmann, Yann Pouget, Milan Vodopivec and Michael Weber, May 2011 (online only)

1110 Portability of Pension, Health, and other Social Benefits: Facts, Concepts, Issues by Robert Holzmann and Johannes Koettl, May 2011 (online only)

1109 Disability and Poverty in Developing Countries: A Snapshot from the World Health Survey by Sophie Mitra, Aleksandra Posarac and Brandon Vick, April 2011

1108 Advancing Adult Learning in Eastern Europe and Central Asia by Christian Bodewig and Sarojini Hirshleifer, April 2011 (online only) 
1107 Results Readiness in Social Protection \& Labor Operations by Laura Rawlings, Maddalena Honorati, Gloria Rubio and Julie Van Domelen, February 2011

1106 Results Readiness in Social Protection \& Labor Operations: Technical Guidance Notes for Social Service Delivery Projects

by Julie Van Domelen, February 2011

1105 Results Readiness in Social Protection \& Labor Operations: Technical Guidance Notes for Social Safety Nets Task Teams

by Gloria Rubio, February 2011

1104 Results Readiness in Social Protection \& Labor Operations: Technical Guidance Notes for Social Funds Task Teams by Julie Van Domelen, February 2011

1103 Results Readiness in Social Protection \& Labor Operations: Technical Guidance Notes for Labor Markets Task Teams by Maddalena Honorati, February 2011

1102 Natural Disasters: What is the Role for Social Safety Nets?

by Larissa Pelham, Edward Clay and Tim Braunholz, February 2011

$1101 \quad$ North-South Knowledge Sharing on Incentive-based Conditional Cash Transfer Programs

by Lawrence Aber and Laura B. Rawlings, January 2011

1008 Social Policy, Perceptions and the Press: An Analysis of the Media's Treatment of Conditional Cash Transfers in Brazil

by Kathy Lindert and Vanina Vincensini, December 2010 (online only)

1007 Bringing Financial Literacy and Education to Low and Middle Income Countries: The Need to Review, Adjust, and Extend Current Wisdom by Robert Holzmann, July 2010 (online only)

1006 Key Characteristics of Employment Regulation in the Middle East and North Africa by Diego F. Angel-Urdinola and Arvo Kuddo with support from Kimie Tanabe and May Wazzan, July 2010 (online only)

1005 Non-Public Provision of Active Labor Market Programs in Arab-Mediterranean Countries: An Inventory of Youth Programs

by Diego F. Angel-Urdinola, Amina Semlali and Stefanie Brodmann, July 2010 (online only)

1004 The Investment in Job Training: Why Are SMEs Lagging So Much Behind? by Rita K. Almeida and Reyes Aterido, May 2010 (online only) 
1003 Disability and International Cooperation and Development: A Review of Policies and Practices

by Janet Lord, Aleksandra Posarac, Marco Nicoli, Karen Peffley, Charlotte

McClain-Nhlapo and Mary Keogh, May 2010

1002 Toolkit on Tackling Error, Fraud and Corruption in Social Protection Programs by Christian van Stolk and Emil D. Tesliuc, March 2010 (online only)

1001 Labor Market Policy Research for Developing Countries: Recent Examples from the Literature - What do We Know and What should We Know?

by Maria Laura Sanchez Puerta, January 2010 (online only)

0931 The Korean Case Study: Past Experience and New Trends in Training Policies by Young-Sun Ra and Kyung Woo Shim, December 2009 (online only)

0930 Migration Pressures and Immigration Policies: New Evidence on the Selection of Migrants

by Johanna Avato, December 2009 (online only)

0929 Ex-Ante Methods to Assess the Impact of Social Insurance Policies on Labor Supply with an Application to Brazil

by David A. Robalino, Eduardo Zylberstajn, Helio Zylberstajn and

Luis Eduardo Afonso, December 2009 (online only)

0928 Rethinking Survivor Benefits

by Estelle James, December 2009 (online only)

0927 How Much Do Latin American Pension Programs Promise to Pay Back? by Alvaro Forteza and Guzmán Ourens, December 2009 (online only)

0926 Work Histories and Pension Entitlements in Argentina, Chile and Uruguay by Alvaro Forteza, Ignacio Apella, Eduardo Fajnzylber, Carlos Grushka, Ianina Rossi and Graciela Sanroman, December 2009 (online only)

$0925 \quad$ Indexing Pensions

by John Piggott and Renuka Sane, December 2009 (online only)

$0924 \quad$ Towards Comprehensive Training by Jean Fares and Olga Susana Puerto, November 2009

0923 Pre-Employment Skills Development Strategies in the OECD by Yoo Jeung Joy Nam, November 2009

0922 A Review of National Training Funds by Richard Johanson, November 2009

0921 Pre-Employment Vocational Education and Training in Korea by ChangKyun Chae and Jaeho Chung, November 2009 

and Practices

by Arvo Kuddo, November 2009 (online only)

0919 Openness and Technological Innovation in East Asia: Have They Increased the Demand for Skills?

by Rita K. Almeida, October 2009 (online only)

0918 Employment Services and Active Labor Market Programs in Eastern European and Central Asian Countries by Arvo Kuddo, October 2009 (online only)

0917 Productivity Increases in SMEs: With Special Emphasis on In-Service Training of Workers in Korea by Kye Woo Lee, October 2009 (online only)

$0916 \quad$ Firing Cost and Firm Size: A Study of Sri Lanka's Severance Pay System by Babatunde Abidoye, Peter F. Orazem and Milan Vodopivec, September 2009 (online only)

0915 Personal Opinions about the Social Security System and Informal Employment: Evidence from Bulgaria

by Valeria Perotti and Maria Laura Sánchez Puerta, September 2009

0914 Building a Targeting System for Bangladesh based on Proxy Means Testing by Iffath A. Sharif, August 2009 (online only)

0913 Savings for Unemployment in Good or Bad Times: Options for Developing Countries

by David Robalino, Milan Vodopivec and András Bodor, August 2009 (online only)

0912 Social Protection for Migrants from the Pacific Islands in Australia and New Zealand by Geoff Woolford, May 2009 (online only)

0911 Human Trafficking, Modern Day Slavery, and Economic Exploitation by Johannes Koettl, May 2009

$0910 \quad$ Unemployment Insurance Savings Accounts in Latin America: Overview and Assessment by Ana M. Ferrer and W. Craig Riddell, June 2009 (online only)

0909 Definitions, Good Practices, and Global Estimates on the Status of Social Protection for International Migrants by Johanna Avato, Johannes Koettl, and Rachel Sabates-Wheeler, May 2009 (online only)

0908 Regional Overview of Social Protection for Non-Citizens in the Southern African Development Community (SADC) by Marius Olivier, May 2009 (online only) 
0907 Introducing Unemployment Insurance to Developing Countries by Milan Vodopivec, May 2009 (online only)

0906 Social Protection for Refugees and Asylum Seekers in the Southern Africa Development Community (SADC) by Mpho Makhema, April 2009 (online only)

0905 How to Make Public Works Work: A Review of the Experiences by Carlo del Ninno, Kalanidhi Subbarao and Annamaria Milazzo, May 2009 (online only)

0904 Slavery and Human Trafficking: International Law and the Role of the World Bank

by María Fernanda Perez Solla, April 2009 (online only)

0903 Pension Systems for the Informal Sector in Asia edited by Landis MacKellar, March 2009 (online only)

0902 Structural Educational Reform: Evidence from a Teacher’s Displacement Program in Armenia by Arvo Kuddo, January 2009 (online only)

0901 Non-performance of the Severance Pay Program in Slovenia by Milan Vodopivec, Lilijana Madzar, Primož Dolenc, January 2009 (online only)

To view Social Protection Discussion papers published prior to 2009, please visit www.worldbank.org/sp. 
